\title{
Molecular basis of CYP19A1 deficiency in a 46, XX patient with R550W mutation in POR: Expanding the PORD phenotype.
}

\author{
Shaheena Parween ${ }^{1,2, \lambda}$, Mónica Fernández-Cancio ${ }^{3, \lambda}$, Sara Benito-Sanz ${ }^{4}$, Núria Camats ${ }^{3}$, Maria \\ Natalia Rojas Velazquez ${ }^{1,2,5}$, Juan-Pedro López-Siguero ${ }^{6}$, Sameer S Udhane ${ }^{1,2, \#}$, Norio Kagawa ${ }^{7}$, \\ Christa E Flück ${ }^{1,2}$, Laura Audî̉ and Amit V. Pandey ${ }^{1,2, *}$
}

${ }^{1}$ Pediatric Endocrinology, Diabetology and Metabolism, University Children's Hospital, Bern, Switzerland

${ }^{2}$ Department of Biomedical Research, University of Bern, Bern, Switzerland

${ }^{3}$ Growth and Development Research Unit VHIR, Hospital Vall d'Hebron, CIBERER, Autonomous University of Barcelona, Barcelona, Spain

${ }^{4}$ Instituto de Genética Médica y Molecular (INGEMM), Hospital Universitario La Paz, CIBERER, ISCIII, Madrid, Spain

${ }^{5}$ Laboratorio de Genética Molecular, Departamento de Genética, Instituto de Investigaciones en Ciencias de la Salud, Universidad Nacional de Asunción, Paraguay.

${ }^{6}$ Pediatric Endocrinology Unit, Hospital Carlos Haya, Universidad de Málaga, Spain

${ }^{7}$ Faculty of Medicine, Nagoya University, Nagoya, Japan

$\lambda$ These authors contributed equally to this manuscript and should be considered co-first authors.
\# Current address: Department of Pathology, Medical College of Wisconsin Cancer Center,
Milwaukee, WI 53226, USA.

* Address for correspondence and reprint requests:

PD Dr. Amit V Pandey

KIKL C837, Pediatric Endocrinology, Diabetology \& Metabolism,

University Children's Hospital Bern,

Freiburgstrasse 15, CH-3010 Bern Switzerland

Tel: 0041316329637

Email: amit@pandeylab.org

Keywords: PORD; congenital adrenal hyperplasia; POR; CY19A1; CYP21A2, CYP17A1.

Funding: This work was supported in part by grants from the Swiss National Science Foundation (31003A-134926), the Novartis Foundation for Medical-Biological Research (18A053) and Burgergemeinde Bern to AVP, and from Fondo de Investigación Sanitaria, ISCIII, Spain (PI05/01647) to SB-S and MF-C.

Disclosure Summary: Authors have nothing to disclose.

(C) Endocrine Society 2020. All rights reserved. For permissions, please e-mail: journals.permissions@oup.com. jc.2019-40036. See endocrine.org/publications for Accepted Manuscript disclaimer and additional information. 


\begin{abstract}
Context: Mutations in Cytochrome P450 oxidoreductase (POR) cause a form of congenital adrenal hyperplasia (CAH). We are reporting a novel R550W mutation in POR identified in a 46, XX patient with signs of aromatase deficiency.
\end{abstract}

Objective: Analysis of aromatase deficiency from R550W mutation in POR.

Design, setting, and patient: Both the child and the mother had signs of virilization. Ultrasound revealed the presence of uterus and ovaries. No defects in CYP19A1 were found, but further analysis with a targeted Disorders of Sexual Development NGS panel (DSDSeq.V1,111 genes) on a NextSeq (Illumina) platform in Madrid and Barcelona, Spain, revealed compound heterozygous mutations c.73_74delCT/p.L25FfsTer93 and c.1648C >T/p.R550W in POR. WT and R550W POR were produced as recombinant proteins and tested with multiple cytochrome P450 enzymes at University Children's Hospital, Bern, Switzerland.

Main outcome measure and Results: R550W POR showed 41\% of the WT activity in cytochrome c and $7.7 \%$ activity for reduction of MTT. Assays of CYP19A1 showed a severe loss of activity and CYP17A1, as well as CYP21A2 activities, were also lost by more than 95\%. Loss of CYP2C9, CYP2C19, and CYP3A4 activities was observed for the R550W-POR. Predicted adverse effect on aromatase activity as well as a reduction in binding of NADPH was confirmed.

Conclusions: Pathological effects due to POR R550W were identified, expanding the knowledge of molecular pathways associated with aromatase deficiency. Screening of the POR gene may provide a diagnosis in $\mathrm{CAH}$ without defects in genes for steroid metabolizing enzymes.

\title{
Précis
}

In a 46, XX patient with aromatase deficiency, a mutation in $P O R$ was identified, which inhibited aromatase activity, expanding the molecular pathogenesis of aromatase deficiency. 


\section{Introduction}

Cytochrome $\mathrm{P} 450$ oxidoreductase (POR) is the redox partner of cytochrome $\mathrm{P} 450$ proteins located in the endoplasmic reticulum (1). POR deficiency (PORD, OMIM: MIM613571 and MIM201750) is a form of congenital adrenal hyperplasia, initially described in patients with altered steroidogenesis (2-4) followed by several reports with a broad spectrum of disorders (5-7). In 2004, mutations in POR disrupting steroid biosynthesis were reported $(2,6,7)$, and in subsequent reports, a range of POR mutations causing disorders of sexual development with and without bone malformation have been described (5,8-11). Human POR is a 680 amino acid protein that has evolved from ferredoxin and ferredoxin reductase-like domains to form a single redox protein in eukaryotes. POR was identified by studies of $\mathrm{Lu}$ and Coon as a component of microsomal mixed oxidase system along with lipids and cytochrome $\mathrm{P} 450$ proteins (12). POR transfers redox equivalents from the reduced form of nicotinamide adenine dinucleotide phosphate (NADPH) to cytochrome $\mathrm{P} 450$ proteins for their catalytic activities (13) (Figure 1). Also, POR can reduce heme oxygenase, cytochrome $b_{5}$, and a range of small molecules and dyes like ferricyanide (FeCN), 3-(4,5-dimethylthiazol-2-yl)-2,5-diphenyltetrazolium bromide (MTT), etc $(1,14)$. Due to its unique role in a range of metabolic processes, POR is an essential protein and POR knockout mouse are embryonically lethal (15). POR deficiency was initially identified as a disorder of sex development with ambiguous genitalia resembling some features of Antley-Bixler bone malformation syndrome. However, after findings of multiple genetic defects in POR from patients both with and without bone malformation features, PORD is now considered a separate genetic disorder different from the Antley-Bixler syndrome which is due to presence of mutations in fibroblast growth factor receptor 2 (FGFR2) and without defects in steroid metabolism (1,8,16-18).

Due to the involvement of POR in multiple reactions in the metabolism of both the steroids and drugs, exact effects of individual mutations in POR are hard to predict and require extensive characterization by enzymatic and biochemical analysis $(2,8,19-26)$. Therefore, the exact mechanisms by which mutations in POR cause pathogenesis, remain mostly unknown. From the characterization of multiple mutations in POR by us as well as other laboratories, some general conclusions could be drawn. Mutations in POR that result in loss of flavin co-factors (FAD and FMN) show a severe loss of enzymatic activities and cause a lethal form of POR deficiency. Mutations located in the hinge region of POR that is necessary for FMN and FAD domain movements cause a phenotypically variable form of the disease and impact different P450 enzyme activities to different extents. Mutations located near the NADPH binding site of POR may impact the activities of multiple cytochrome P450 activities, but the impact on individual enzymes could be variable. We have reported a study of structural stability and sequence conservation analysis to find out which POR variants may be potentially disease-causing (27). 
Aromatase is a 503 amino acid protein (NP_000094) encoded by the CYP19A1 gene (MIM10790, GeneID:1588, NCBI: NM_000103), located on chromosome 15 (15q21.2, GRCh38 15:5120805651338597). CYP19A1 (EC: 1.14.14.14) regulates estrogen biosynthesis in humans (28) by converting androgens to estrogens (29-32). Aromatase is highly expressed in ovaries and plays a significant role in the regulation of the reproductive cycle in females (33). Some of the critical reactions catalyzed by aromatase include the conversion of androstenedione to estrone (E1), testosterone to 17ß-estradiol (E2) and 16-hydroxytestosterone to estriol (E3) (28). The catalytic process of aromatization of androgens is multifaceted, and it comprises of three steps involving the transfer of three pairs of electrons from the reduced form of nicotinamide adenine dinucleotide phosphate (NADPH) and consumption of oxygen. Electron transfer from NADPH to aromatase is carried out by NADPH cytochrome P450 oxidoreductase (POR).

The first case of placental aromatase deficiency was reported by Shozu et al. (34), and aromatase deficiency manifests during fetal life in both sexes (35). Multiple genetic defects are associated with decreased aromatase expression in both male and female reproduction (36). In females, aromatase deficiency affects maternal virilization during gestation, abnormal external genitalia in the female fetus, normal ovarian development but increased polycystic ovary syndrome occurrence and virilization at puberty $(37,38)$. Impact of aromatase deficiency on growth, skeletal maturation, and bone homeostasis, as well as changes in insulin resistance and abnormal plasma lipid profile, have been described in earlier studies $(39,40)$. In a Japanese cohort of PORD patients, homozygous mutation R457H has been linked to genital virilization and aromatase deficiency in 46, XY patients (11) and some earlier cases of aromatase deficiency have been confirmed as PORD in later analysis (41).

Here we have performed a detailed characterization of a novel mutation in POR, R550W, that caused aromatase deficiency in a 46, XX patient and led to maternal virilization during pregnancy. By use of biochemical analysis of patient samples and production of a recombinant form of POR containing the R550W mutation, we have been able to characterize the different enzyme activities affected by the R550W mutation in POR. We investigated the effect of R550W mutation in POR on steroid metabolizing P450 enzymes CYP17A1 (17-hydroxylase activity), CYP21A2 (21-hydroxylase activity) and CYP19A1 (aromatase activity) and could show that CYP19A1 activity was severely affected by the R550W mutation in POR, explaining the cause of virilization observed the in 46, XX female child. Since POR is the redox partner of hepatic drug metabolizing cytochrome P450 enzymes, a mutation in POR may also affect drug metabolism (Figure 2). A large number of drugs are metabolized by cytochrome P450 enzymes in the liver. The major hepatic drug metabolizing enzyme is CYP3A4, which alone metabolizes almost half the drugs in clinical use (42-44). Therefore, we also tested the effect of R550W mutation in POR on activities of four drug-metabolizing cytochromes P450 (CYP2C9, CYP2C19, CYP3A4 and CYP3A5) in addition to testing the direct metabolic activities of POR on small 
molecules (FeCN and MTT) and a soluble probe substrate cytochrome c, to identify different mechanisms that may affect POR due to R550 mutation. Our experiments identified two distinct mechanisms for pathogenicity of the POR mutation R550W: inhibition of CYP19A1 activity leading to virilization of the female child, and the overall reduction in the activities of POR due to loss of flavin content, suggesting protein instability. These results expand our knowledge about the pathology of PORD and disruption of steroidogenesis resulting from mutations in POR. 


\section{Case Report and Methods}

\section{Patient}

The patient was born at term in Málaga (Spain) in 2009, from the $1^{\text {st }}$ pregnancy of non-consanguineous parents. The mother had presented signs of virilization from the $6^{\text {th }}$ month of pregnancy (acne, hirsutism, clitoris growth, and voice deepening) that regressed progressively post-partum. Hormone analyses at post-partum day 5 revealed a highly increased testosterone (T) serum concentration that returned to normal female levels at the four ${ }^{\text {th }}$ postpartum month (Table 1). The child was examined at seven days: length $48 \mathrm{~cm}$ (-1.22 SDS), weight 2,920 g (-1.02 SDS), the external genitalia showed a rugated labia majora, no palpable gonads, genital tubercle of $1.5 \mathrm{~cm}$ with proximal urethral opening, considered as Prader type 3 ambiguous genitalia. At three months, clitoris hypertrophy had regressed. Initial (7 days of age) 17-OH-P and $\mathrm{T}$ were elevated and progressively diminished; $\mathrm{T}$ reached normal female levels from the $1^{\text {st }}$ month, whereas $17-\mathrm{OH}-\mathrm{P}$ was still slightly elevated at seven months (Table 1 ). The karyotype was 46, XX, and 21-hydroxylase deficiency was ruled out since the 17-OHP increased at birth, but the values were below those seen in the classic form of 21-hydroxylase deficiency and showed a progressive reduction. Pelvic ultrasound revealed the presence of uterus and bilateral gonads. Transient intrauterine virilization was diagnosed due to maternal pregnancy luteoma or aromatase deficiency that would explain the transient virilization of the mother and the female child. The CYP19AI gene was sequenced from the DNA of the child, but no pathogenic sequence variant was detected. The patient developed without any further significant clinical manifestations. A genitoplasty was performed at 13 months. At 8 years, there were no signs of adrenarche (no pubic hair) and bone age was 7 years, indicating that there was no increase in androgen levels, despite the elevated 17-OH-P levels.

\section{Hormone assays}

Hormone assays were performed in Málaga (Hospital Carlos Haya), Spain. The 17-OH-P was determined with a commercial radioimmunoassay technique (Coat-A-Count. Siemens Healthcare Diagnostics Ltd. Frimley, Camberley, UK); dehydroepiandrosterone sulfate (DHEA-S), T, estradiol (E2) and cortisol were determined with automated electrochemiluminescent assays (Modular E, Roche Diagnostics GmbH Mannheim, Germany) and ACTH with an automated chemiluminescence immunoassay (LIAISON, DiaSorin, Saluggia, Italy).

\section{Genetic studies}

The study was approved by the Ethics Committee of Hospital Universitari Vall d'Hebron (CEIC), Barcelona, Spain (PR (IR) 23/2016) and parents provided informed consent. Genomic DNA was isolated from whole peripheral blood samples from the patient and her family using standard procedures. The DNA samples were analyzed with a custom-designed targeted Disorders of Sexual Development NGS panel (DSDSeq.V1, 111 genes, and three regulatory regions) using SeqCap EZ 
technology (Roche Nimblegen) and sequenced on a NextSeq500 platform (Illumina) platform. All procedures were carried out according to the manufacturer's instructions. Data analyses were performed using VariantStudio V2.2.1 (Illumina) and in-house bioinformatic analysis as previously described (45). The observed variants were evaluated using the Alamut Visual software v2.11 (https://www.interactivebiosoftware.com/es/alamut-visual/, which includes following pathogenicity prediction tools: Mutation Taster, PolyPhen, Align GVGD and SIFT) MutAssesor, Fasthmm, Vest and CADD V1.4 (https://cadd.gs.washington.edu/). Genome Aggregation Database (gnomAD, http://gnomad.broadinstitute.org), dbSNP (https://www.ncbi.nlm.nih.gov/snp/) and the Collaborative Spanish Variant Server (CSVS; CIBERER BIER, Valencia, Spain; http://csvs.babelomics.org/) were consulted for allelic frequencies. Candidate variants observed by targeted panel (DSDSeq.V1) sequencing as well as segregation analysis in the family were validated and genotyped by Sanger sequencing. Variant classification was performed according to ACMG recommendations (46).

\section{Materials}

Tris-base, NADPH, acetic acid, magnesium acetate, Sucrose, potassium phosphate EDTA, DTT, glycerol, PMSF, and Benzonase were purchased from Sigma-Aldrich Chemie GmbH (Buchs, Switzerland). Carbenicillin, $\mathrm{FeCl}_{3}, \mathrm{ZnCl}_{2}, \mathrm{CoCl}_{2}, \mathrm{Na}_{2} \mathrm{MoO}_{4}, \mathrm{CaCl}_{2}, \mathrm{CuCl}_{2}, \mathrm{M} \mathrm{H}_{3} \mathrm{BO}_{3}$ were purchased from CarlRoth GmBH (Switzerland). Goat anti-rabbit antibodies labeled with infra-red dyes were from LI-COR Bioscience Inc. (NE, USA). The RC-DC protein assay dye reagent was from Bio-Rad (Hercules, CA). The anti-POR antibody was from GenScript (NJ, USA). BOMCC (Invitrogen Corp, Carlsbad, CA, United States).

\section{Expression of POR proteins in bacteria and membrane purification}

The human POR WT and R550W mutant proteins (NCBI\# NP_000932, UniProt\# P16435) were expressed in bacteria using heterologous gene expression $(8,20,26,47)$. The protocol for recombinant expression of POR variants ( $\mathrm{N}-23$ form) and subsequent bacterial membrane purification was based on our previous publications $(8,23,24,26,48)$ with slight modification. Briefly, plasmid (pET15b) containing cDNAs for WT or mutant POR were obtained from GenScript. The Escherichia coli bacterial strain BL21(DE3) was transformed, and single colonies were selected for growth on carbenicillin plate. For the main shake flask culture, autoinduction media consisting of terrific broth supplemented with $40 \mathrm{mM} \mathrm{FeCl}_{3}, 4 \mathrm{mM} \mathrm{ZnCl}_{2}, 2 \mathrm{mM} \mathrm{CoCl}$, $2 \mathrm{mM} \mathrm{Na} 2 \mathrm{MoO}_{4}, 2 \mathrm{mM} \mathrm{CaCl}, 2 \mathrm{mM}$ $\mathrm{CuCl}_{2}, 2 \mathrm{mM} \mathrm{H}_{3} \mathrm{BO}_{3}, 0.5 \mathrm{mg} / \mathrm{ml}$ riboflavin, $100 \mu \mathrm{g} / \mathrm{ml}$ carbenicillin was used. The cells were grown at $37^{\circ} \mathrm{C}$ to an optical density (OD) at $600 \mathrm{~nm}$ of 0.6 , and then the temperature was reduced to $25^{\circ} \mathrm{C}$ and further grown for $16 \mathrm{~h}$. The bacterial cells were collected by centrifugation, washed with PBS and slowly stirred for $1 \mathrm{~h}$ at $4^{\circ} \mathrm{C}$ for in $50 \mathrm{mM}$ Tris-acetate (pH 7.6), $0.25 \mathrm{M}$ sucrose, $0.5 \mathrm{mM}$ EDTA, lysozyme $(0.2 \mathrm{mg} / \mathrm{ml}), 1 \mathrm{mM}$ PMSF and $20 \mathrm{U} / \mathrm{ml}$ endonuclease to prepare spheroplasts. The spheroplasts were collected by centrifugation at $5000 \mathrm{x}$ g for $20 \mathrm{~min}$; and suspended in $50 \mathrm{mM}$ 
potassium phosphate ( $\mathrm{pH} 7.6)$ containing $6 \mathrm{mM}$ Magnesium acetate, $0.1 \mathrm{mM} \mathrm{DTT}, 20 \%$ (v/v) glycerol and $1 \mathrm{mM}$ PMSF; and disrupted by sonication. After centrifugation at $12000 \times \mathrm{g}$ for $15 \mathrm{~min}$ at $4{ }^{\circ} \mathrm{C}$, the supernatant was centrifuged at $100000 \times \mathrm{g}$ for $90 \mathrm{~min}$ at $4{ }^{\circ} \mathrm{C}$ to collect membranes. Purified membranes containing POR were resuspended in $50 \mathrm{mM}$ Potassium phosphate buffer $(\mathrm{pH} 7.8)$ and $20 \%(\mathrm{v} / \mathrm{v})$ glycerol and kept at $-70{ }^{\circ} \mathrm{C}$. Protein concentration was measured by the RC-DC protein assay method (Protein Assay Dye Reagent, Bio-Rad, Hercules, CA) and POR content in membrane proteins was measured by western blot analysis.

\section{Western Blot Analysis of POR Content in the Bacterial Membranes}

Western blot analysis to determine POR content in membranes was done as described previously $(24,49)$. Briefly, $1 \mu \mathrm{g}$ of bacterial membrane proteins were separated on an SDS-PAGE gel and blotted on to polyvinyl difluoride (PVDF) membranes. Blots were first incubated with a rabbit polyclonal antibody against POR-WT from GenScript (GenScript, NJ, USA) at a dilution of 1:1000. We then used a secondary goat anti-rabbit antibody labeled with an infrared dye (IRDye 680RD, LI-COR Bioscience Inc., NE, USA) at a 1:15000 dilution. Signals were analyzed with the $700 \mathrm{~nm}$ fluorescent channel on an Odyssey Infrared Imaging System (LI-COR Bioscience Inc., NE, USA), and protein bands were quantitated using the Odyssey software (LI-COR Bioscience Inc., NE, USA). Purified wild-type POR was used as a standard for normalizing the POR content of each membrane preparation in all experiments described here, the normalized amount of POR content was used for POR-WT and PORP550W protein.

\section{Small molecule Reduction Assay by POR-WT and POR-R550W}

Cytochrome c reduction by POR-WT or POR-R550W was performed as described previously by measuring the change in absorbance at $550 \mathrm{~nm}\left(\varepsilon=21.1 \mathrm{~cm}^{-1} \mathrm{mM}^{-1}\right)(50)$. In brief, varying concentrations of cytochrome $\mathrm{c}(1.3-40 \mu \mathrm{M})$ were mixed with membrane preparations containing $1 \mu \mathrm{g}$ POR in $100 \mathrm{mM}$ phosphate buffer ( $\mathrm{pH}$ 7.6) in a total volume of $100 \mu$ l. The reaction was started by the addition of NADPH, and the change in absorbance at $550 \mathrm{~nm}$ was monitored over 6 minutes. The reaction was performed in 96-well plates, in triplicate, using a microplate reader (Spectramax M2e, Molecular Devices, Sunnyvale, CA). Data were fitted based on Michaelis-Menten kinetics using GraphPad Prism (GraphPad Software, La Jolla, CA USA) to determine the $\mathrm{V}_{\max }$ and $\mathrm{K}_{\mathrm{m}}$. The MTT [3(4,5-dimethylthiazol- 2-yl)-2,5-diphenyltetrazolium] reduction assay was carried out using different concentrations of MTT (3.9-500 $\mu \mathrm{M})$, by measuring the rate of increase in absorbance at $610 \mathrm{~nm}($ $\left.\varepsilon_{610}=11 \mathrm{mM}^{-1} \mathrm{~cm}^{-1}\right)(51)$. The reaction mixture consisted of bacterial membranes containing $1 \mu \mathrm{g}$ POR in $100 \mathrm{mM}$ phosphate buffer (pH 7.6) and $100 \mu \mathrm{M}$ NADPH. Similarly, the ferricyanide reduction was measured as the rate of decrease in absorbance at $420 \mathrm{~nm}\left(\varepsilon_{420}=1.02 \mathrm{mM}^{-1} \mathrm{~cm}^{-1}\right)$. The reaction was started by adding $100 \mu \mathrm{M}$ NADPH and the concentration of ferricyanide varied from 1.3 to $500 \mu \mathrm{M}$ 
(52). Activities represent the mean of at least three replicates. For NADPH variation analysis, cytochrome c $(40 \mu \mathrm{M})$ and MTT $(500 \mu \mathrm{M})$ were kept constant, and NADPH concentration was varied from $0.8-100 \mu \mathrm{M}$.

\section{Flavin Content Analysis of WT and Mutant POR}

Flavins were extracted by thermal denaturation of POR proteins and analyzed as described previously (53). POR-WT or POR-R550W (100 $\mu \mathrm{g} / \mathrm{ml})$ were denatured by heating at $95^{\circ} \mathrm{C}$ for $10 \mathrm{~min}$ in the dark and flavins were separated by centrifugation at $14000 \mathrm{x}$ g for $10 \mathrm{~min}$ from the precipitated protein. The fluorescence of the supernatants was measured at $\mathrm{pH} 7.7$ and $\mathrm{pH} 2.6$ to determine FMN and FAD ratio (excitation at $450 \mathrm{~nm}$, emission at $535 \mathrm{~nm}$ ).

\section{Expression and Purification of human CYP19A1}

The recombinant human CYP19A1 was expressed and purified, as described previously (54) with some modifications. Briefly, a single colony of E. coli BL21(DE3) transformed with expression vectors for CYP19A1, and molecular chaperones GroEL/GroES, was selected for protein expression. A 1:100 dilution of overnight growth culture was used to inoculate the autoinduction medium (terrific broth, 40 $\mathrm{mM} \mathrm{FeCl}, 4 \mathrm{mM} \mathrm{ZnCl}_{2}, 2 \mathrm{mM} \mathrm{CoCl}_{2}, 2 \mathrm{mM} \mathrm{Na}_{2} \mathrm{MoO}_{4}, 2 \mathrm{mM} \mathrm{CaCl}_{2}, 2 \mathrm{mM} \mathrm{CuCl}_{2}, 2 \mathrm{mM} \mathrm{H}_{3} \mathrm{BO}_{3}, 100$ $\mu \mathrm{g} / \mathrm{ml}$ carbenicillin and $50 \mu \mathrm{g} / \mathrm{ml}$ kanamycin). After $4 \mathrm{~h}$ of incubation at $25^{\circ} \mathrm{C}, 1 \mathrm{mM} \delta$-aminolevulinic acid and $4 \mathrm{mg} / \mathrm{ml}$ arabinose (for induction of molecular chaperones GroEL/GroES) were added, and the culture was grown for another $20 \mathrm{~h}$. Bacteria were then harvested, washed with PBS, and stored at -80 ${ }^{\circ} \mathrm{C}$. Bacterial pellet was resuspended in $50 \mathrm{mM}$ Tris-Acetate ( $\mathrm{pH}$ 7.6), $250 \mathrm{mM}$ sucrose, $0.5 \mathrm{mM}$ EDTA, and $0.2 \mathrm{mg} / \mathrm{ml}$ lysozyme to prepare spheroplasts. For purification, spheroplasts were lysed using $10 \mathrm{x}$ CellLytic B (Sigma-Aldrich) in a $100 \mathrm{mM}$ potassium phosphate $(\mathrm{pH} 7.4)$ buffer containing $20 \%$ glycerol, $500 \mathrm{mM}$ sodium acetate, $0.1 \mathrm{mM}$ DTT, $0.1 \mathrm{mM}$ EDTA and $1 \mathrm{mM}$ PMSF. The supernatants after centrifugation were pooled and CYP19A1 was purified by $\mathrm{Ni}^{2+}$ metal-chelate chromatography at $4{ }^{\circ} \mathrm{C}$ using $200 \mathrm{mM}$ histidine for elution. Eluted protein was dialyzed to remove histidine, and protein concentration was determined by RC-DC protein assay (Protein Assay Dye Reagent, Bio-Rad, Hercules, CA) using BSA as standard.

\section{Cytochrome P450 CYP17A1 enzyme activity supported by WT and POR-R550W}

Purified recombinant CYP17A1 was used to test the effect of POR-R550W to support the $17 \alpha-$ hydroxylase activity of CYP17A1. Bacterial membranes containing POR and purified CYP17A1 (CYPEX, Dundee, Scotland, United Kingdom) were reconstituted as described previously $(8,49,55,56)$ and $17 \alpha$-hydroxylase activity of CYP17A1 was measured by using progesterone as substrate. The reaction mixture consisted of 30 pmol of CYP17A1, 60 pmol of POR, and ${ }^{14} \mathrm{C}$ labeled progesterone $(50000 \mathrm{cpm})$ in $50 \mathrm{mM}$ potassium phosphate buffer $(\mathrm{pH}$ 7.4). The reaction mixture was supplemented 
with $10 \mathrm{mM}$ magnesium chloride, $6 \mathrm{mM}$ potassium acetate, and $1 \mathrm{mM}$ reduced glutathione. Progesterone concentration was varied from $0.3 \mu \mathrm{M}$ to $5 \mu \mathrm{M}$ for kinetic analysis, and the reaction was initiated by the addition of $2 \mathrm{mM}$ NADPH and incubated for $60 \mathrm{~min}$ at $37^{\circ} \mathrm{C}$. Data were fitted based on Michaelis-Menten kinetics using GraphPad Prism (GraphPad Software, La Jolla, CA USA).

\section{Assay of cytochrome P450 CYP21A2 enzyme activity supported by WT and POR-R550W}

Purified recombinant CYP21A2 was used to test the effect of POR-R550W to support the 21hydroxylase activity of CYP21A2. Bacterial membranes containing POR and purified CYP21A2 (CYPEX, Dundee, Scotland, United Kingdom) were reconstituted as described previously $(8,49,55,56)$ and 21-hydroxylase activity of CYP21A2 was measured using progesterone as the substrate. The reaction mixture consisted of $20 \mathrm{pmol}$ of CYP21A2, $40 \mathrm{pmol}$ of POR, and ${ }^{14} \mathrm{C}$ labeled progesterone $(50000 \mathrm{cpm})$ in $50 \mathrm{mM}$ potassium phosphate buffer (pH 7.4). The reaction mixture was supplemented with $10 \mathrm{mM}$ magnesium chloride, $6 \mathrm{mM}$ potassium acetate, and $1 \mathrm{mM}$ reduced glutathione. Different concentrations $(0.3-5 \mu \mathrm{M})$ of progesterone were used for kinetic analysis, and the reaction was initiated by the addition of $2 \mathrm{mM}$ NADPH and incubated for $60 \mathrm{~min}$ at $37{ }^{\circ} \mathrm{C}$. Data were fitted based on Michaelis-Menten kinetics using GraphPad Prism (GraphPad Software, La Jolla, CA USA).

\section{Cytochrome P450 CYP19A1 enzyme activity supported by WT and POR-R550W}

Purified recombinant CYP19A1 using the bacterial expression system was used to test the effect of POR-R550W to support the aromatase activity. Aromatase activity was measured by the tritiated water release assay based on an earlier method described by Lephart and Simpson (57) with some modifications $(26,49)$ using a reconstituted system and androstenedione (androst-4-ene-3,17-dione) as

the substrate. Bacterial membranes containing POR and purified CYP19A1 were reconstituted in a 1:2 ratio. Reaction mixture consisted of 50 pmol of POR, 100 pmol of CYP19A1 and tritium labeled androstenedione $\left(\left[1^{1}-3 \mathrm{H}(\mathrm{N})\right]\right.$-andros-tene-3,17-dione; $\left.~ 15,000 \mathrm{cpm}\right)$ in $100 \mathrm{mM}$ potassium phosphate buffer ( $\mathrm{pH} 7.4)$ with $100 \mathrm{mM} \mathrm{NaCl}$. Different concentrations (10-1000 nM) of androstenedione were used for kinetic analysis. The aromatase reaction was started by addition of $1 \mathrm{mM}$ NADPH and was incubated for $60 \mathrm{~min}$ at $37^{\circ} \mathrm{C}$. After incubation, $0.8 \mathrm{ml}$ of $5 \%$ charcoal $/ 0.5 \%$ dextran solution was added to the reaction mixture. Reaction tubes were mixed by vortex and centrifuged at $15000 \mathrm{x} g$ for 5 minutes. From each tube, $0.5 \mathrm{ml}$ of supernatant was used for radioactivity measurement. Values obtained from duplicate experiments are expressed as mean \pm S.E.M. (standard error of the mean). Data were fitted based on Michaelis-Menten kinetics using GraphPad Prism (GraphPad Software, La Jolla, CA USA). For NADPH kinetic analysis, androstenedione concentration was kept constant at $100 \mathrm{nM}$, and NADPH was varied from $62.5-1000 \mu \mathrm{M}$. 
The activity of CYP2C9 supported by WT or mutant POR was tested using in vitro reconstituted system. It consisted of bacterial membranes containing WT/R550W POR, purified CYP2C9 (CYPEX, Dundee, Scotland, United Kingdom) and purified cytochrome $b_{5}$ at a ratio of 5:1:1 (58). The fluorogenic compound BOMCC (7-Benzyloxy-4-trifluoromethylcoumarin) (Invitrogen Corp, Carlsbad, CA, United States) was used as substrate. $100 \mu \mathrm{L}$ of assay mixture consisted of $5 \mu \mathrm{g}$ DLPC (1,2-Dilauroyl-snglycero-3-phosphocholine), $3 \mathrm{mM} \mathrm{MgCl} 2$ and $20 \mu \mathrm{M}$ BOMCC in $100 \mathrm{mM}$ Tris- $\mathrm{HCl}$ buffer (pH 7.4). 1 $\mathrm{mM}$ NADPH was added to start the reaction and fluorescence was measured on a Spectramax M2e plate reader (Molecular Devices, Sunnyvale, CA, United States) at an excitation wavelength of $415 \mathrm{~nm}$ and an emission wavelength of $460 \mathrm{~nm}$ for BOMCC.

\section{Cytochrome P450 CYP2C19 activity supported by WT and POR-R550W}

The activity of CYP2C19 supported by WT or POR-R550W was tested using the fluorogenic substrate EOMCC (Invitrogen Corp, Carlsbad, CA, United States). In vitro, CYP2C19 assays were performed using a reconstituted system consisting of WT/POR-R550W, CYP2C19 (CYPEX, Dundee, Scotland, United Kingdom) and cytochrome $b_{5}$ at a ratio of 5:1:1 (58). It consisted of $2.5 \mu \mathrm{g}$ DLPC and proteins (0.5 $\mu$ M POR: $100 \mathrm{nM}$ CYP2C19: $100 \mathrm{nM} \mathrm{b}_{5}$ ), $3 \mathrm{mM} \mathrm{MgCl}_{2}, 20 \mu \mathrm{M}$ EOMCC in $100 \mu \mathrm{L}$ of $100 \mathrm{mM}$ Tris- $\mathrm{HCl}$ buffer ( $\mathrm{pH}$ 7.4). The reaction was started by addition of $0.5 \mathrm{mM} \mathrm{NADPH}$, and fluorescence was measured on a Spectramax M2e plate reader (Molecular Devices, Sunnyvale, CA, United States) at an excitation wavelength of $415 \mathrm{~nm}$ and an emission wavelength of $460 \mathrm{~nm}$ for EOMCC.

\section{Cytochrome P450 CYP3A4 Activity supported by WT and POR-R550W}

The activity of the major drug-metabolizing enzyme CYP3A4 supported by WT or POR-R550W was tested using the fluorogenic substrate, BOMCC, as described earlier (59). An in-vitro reconstituted system was used by mixing POR (WT or R550W), purified CYP3A4 (CYPEX, Dundee, Scotland, UK) and cytochrome b5 as described above at a ratio of 5:1:1 (58). The final assay mixture consisted of proteins ( $1 \mu$ M POR: $200 \mathrm{nM}$ CYP3A4: $200 \mathrm{nM} \mathrm{b}_{5}$ ), $3 \mathrm{mM} \mathrm{MgCl}_{2}, 5 \mu \mathrm{g}$ DLPC and $20 \mu \mathrm{M}$ BOMCC in $100 \mu \mathrm{L}$ of $100 \mathrm{mM}$ Tris-HCl buffer (pH 7.4). $1 \mathrm{mM} \mathrm{NADPH}$ was added to start the reaction and progress of the reaction was monitored by fluorescence Spectrophotometer (Spectramax M2e plate reader; Molecular Devices, Sunnyvale, CA) with sample excitation at $415 \mathrm{~nm}$ and emission at $460 \mathrm{~nm}$.

\section{Cytochrome P450 CYP3A5 activity supported by WT and POR-R550W}

The activity of CYP3A5 supported by WT or POR-R550W was tested using the in-vitro reconstituted system as described above. The purified CYP3A5 (CYPEX, Dundee, Scotland, United Kingdom), $\mathrm{WT} /$ mutant POR, and cytochrome $\mathrm{b}_{5}$ were mixed at a ratio of 1:5:1 (58). The assay mixture $(100 \mu \mathrm{L})$ consisted of $5 \mu \mathrm{g}$ DLPC and proteins ( $1 \mu \mathrm{M}$ POR: $200 \mathrm{nM}$ CYP3A5: $200 \mathrm{nM} \mathrm{b}$ ), $3 \mathrm{mM} \mathrm{MgCl}_{2}, 20 \mu \mathrm{M}$ BOMCC in $100 \mathrm{mM}$ Tris-HCl buffer (pH 7.4) and the reaction was started by addition of NADPH to 1 $\mathrm{mM}$ final concentration. Fluorescence was monitored for one hour. 


\section{D protein models}

To study the potential impact of the mutation on structure, 3D models of POR-WT and POR-R550W were prepared using previously published model building protocols.

\section{Statistical Analysis of results}

Data are shown as mean, standard errors of the mean (SEM) in each group or replicates. Differences within the subsets of experiments were calculated using Student's t-test. P values less than 0.05 were considered statistically significant.

\section{Results}

\section{Identification of compound heterozygous variants in POR in CYP19A1 deficiency}

Custom-designed targeted DSD NGS panel (DSDSeq.V1) revealed compound heterozygous variants in POR (NM_000941.2): c.73_74delCT/p.(L25Ffs*93) and c.1648C >T/p.(R550W) in the patient (46, XX karyotype). Sanger sequencing confirmed the segregation, the mother carried for the frameshift c.73_74delCT/p.(L25Ffs*93) and the father for the missense variant, c.1648C>T/p.(R550W) (Figure 3). A younger normal brother carried the c. $1648 \mathrm{C}>\mathrm{T}$ p. ( R550W) variant. No further variants of interest were identified in the DSDSeq.V1 panel. At 8 years, the patient is prepubertal, and growth is normal (height 0.1 SDS and weight -0.41 SDS). No skeletal anomalies were detected, and the baseline hormonal analysis revealed normal DHEA-S, cortisol, T, and ACTH while 17OH-P was elevated (Table 1). Recommendations related to the stress situation needing glucocorticoid therapy were given to parents.

\section{Both POR variants found in the patient are observed as rare variants in genome databases}

The POR variants identified in the patient in this report have been observed as rare variants in the genome databases (Table 2). The Arginine 550 residue studied here is highly conserved across species. The variant c.1648C>T/p.(R550W) (rs782551496) which has a MAF of 0.00004671 (GnomAD) was classified as a variant of uncertain significance (VUS) and predicted to be pathogenic with multiple pathogenicity prediction tools. Another variant at the same position, R550Q only had data available for the Global population (Table 2). The variant c.73_74delCT/p.(L25Ffs*93) (rs782696006) has a population minor allele frequency (MAF) of 0.000008125 (GnomAD), is classified as likely pathogenic following recommendations of ACGM, and due to truncation would generate a non-functional POR protein which would be unable to support the aromatase activity. 
Arginine 550 is located near NADPH binding site in POR and mutation R550W creates protein instability

To differentiate between the POR-WT and POR-R550W, we performed in-silico mutagenesis using the x-ray crystal structure of human POR. Human POR has distinct domains for the binding of NADPH/FAD and FMN (Figure 4A). The FMN binding domain interacts with the redox partners and is required for electron transfer to partner proteins. The redox equivalents for the electron transfer are provided by NADPH which is used as a substrate by POR and converted to NADP. The R550 residue is not directly at the surface of POR but is located near the NADPH binding pocket (Figure 4B). In the WT-POR, the arginine 550 residue forms hydrogen bonds with threonine 529 to stabilize the NADPH binding domain (Figure 4C). Mutation of arginine 550 to tryptophan results in loss of hydrogen bond interactions and destabilization of the POR protein. Binding of NADPH has also been associated in providing stability to POR and disruption of NADPH binding due to mutation of arginine 550 to tryptophan is predicted to cause protein instability.

\section{The R550W mutation in POR results in reduced flavin content}

To differentiate the conformational changes and effects of POR mutation R550W on flavin binding, we evaluated the relative flavin content since the activity of POR may be affected by the changes in the binding of cofactors FMN and FAD. As compared to WT POR, both the FMN and the FAD-binding was affected due to R550W mutation. As compared to WT, the FMN and FAD content of POR-R550W was $63.4 \%$ and $68.7 \%$ respectively. This suggests that POR-R550W affects both FMN as well as FAD binding to POR (Figure 5). Since the R550 residue is not directly involved in either the FAD or the FMN binding, loss of flavins suggests an overall instability of protein due to R550W mutation. It has been shown previously that binding of NADPH may affect the FAD/FMN binding in POR, and therefore, R550W mutation in POR may create a conformational change that is less favorable for the binding of FAD as well as FMN.

\section{Small molecule Reduction Activity of POR is adversely affected by the R550W mutation.}

To study the effect of the R550W mutation on POR activity, we expressed WT and POR- R550W in $E$. coli as N-23 form and purified bacterial membranes. The ability to transfer electrons from NADPH to cytochrome c, MTT or ferricyanide by POR-WT or POR-R550W was tested. The POR-R550W mutation had a much lower capacity to reduce cytochrome c, MTT, and ferricyanide (Table 3, Figure 6A-C). Compared to WT POR, the R550W variant lost $\sim 60 \%$ cytochrome c reduction activity and $\sim 70 \%$ of ferricyanide reduction activity. The MTT reduction activity (Table 3, Figure 6B) was also severely affected by the R550W mutation, with only $8 \%$ residual activity observed compared to WTPOR. The loss of activities with ferricyanide indicates disruption of electron transport from NADPH to FAD and loss of cytochrome $\mathrm{c}$ and MTT reduction activities indicates disruption of electron transfer between the two flavins and from FMN to the redox partners. Conformational instability due to an 
R550W mutation might be affecting domain movements and transfer of electrons from NADPH to FAD, FMN, and acceptor molecules. Since Ferricyanide reduction can proceed even without a functional FMN domain in POR, loss of Ferricyanide reduction activity could either be due to a disruption of electron transfer from NADPH to FAD or the loss of FAD-binding as reported above and a combination of these two factors. The cytochrome $\mathrm{c}$ and MTT reduction by POR requires a functional FMN domain in addition to the intact NADPH/FAD-binding domain. However, we have seen MTT reduction activity to be a better indicator of the effect on steroid metabolizing enzymes, and here the loss of MTT reduction activity was much severe compared to a loss of cytochrome c reduction activity.

\section{CYP17A1- 17a-hydroxylase Activity}

After the observation of lower activities of the R550W mutant of POR towards the reduction of small molecule substrates, we sought to examine the effect of arginine to tryptophan at the position 550 in POR on the activities of several steroid metabolizing cytochrome P450 enzymes that are dependent on POR for their enzymatic reactions. Towards this goal, we first examined the effect of POR-R550W on the 17-hydroxylase activity of CYP17A1, which is considered the qualitative regulator of steroidogenesis in human and guides the formation of steroids towards different pathways. The PORR550W lost almost all 17 $\alpha$-hydroxylase activity of CYP17A1 (Figure 7A, Table 3). For the PORR550W variant, the apparent Vmax was reduced by $\sim 95 \%$ without affecting the apparent $\mathrm{Km}$ as compared to WT POR. The POR variant R550W showed only 3\% residual activity in supporting CYP17A1 as compared to WT POR.

\section{The 21-hydroxylase activity of CYP21A2 is severely affected by the R550W mutation in POR}

The CYP21A2 is involved in the regulation of corticosteroids and is a critical enzyme in the steroid metabolism in human. Defects in CYP21A2 cause the most common form of congenital adrenal hyperplasia and mutation in POR may resemble CYP21A2 deficiency due to adverse effects of a malfunctioning POR on the activities of CYP21A2. The POR-R550W showed highly reduced CYP21A2 activity (Figure 7B, Table 3). The apparent Vmax of POR-R550W was reduced by $~ 98 \%$. The POR variant R550W showed only $3 \%$ residual activity in supporting CYP21A2 as compared to WT POR.

\section{POR mutation R550W causes severe disruption of the aromatase activity of CYP19A1}

Since the patient showed symptoms of aromatase deficiency as indicated by genital virilization, we were particularly interested in examining the role of R550W mutation in POR on the CYP19A1 activity. Compared to other cytochromes P450 studied in this report, CYP19A1 requires additional steps of electron transfer from POR to complete a single reaction cycle, and therefore, is predicted to be severely affected by changes in POR that affect electron transfer from POR to CYP19A1. The POR-R550W showed a severe effect on CYP19A1 activity (Figure 7C, Table 3). The apparent Vmax of POR- 
R550W was reduced to $16 \%$ of WT-POR and $25 \%$ of residual activity was observed in CYP19A1 reaction kinetics, due to a slight decrease in $\mathrm{Km}$ for the androstenedione observed in reactions supported by POR-R550W (Table 3). A significant loss of CYP19A1 activity confirmed the diagnosis of aromatase deficiency and genital virilization in the patient.

\section{CYP2C9 Activity}

We tested the activity of CYP2C9 supported by the WT and R550W variant of POR in a reconstituted system. Compared to WT POR activity of CYP2C9 supported by R550W variant of POR was severely reduced to $2.5 \%$ of the WT-POR (Figure 8A). This almost complete loss of activity compared to WT POR indicated a severe effect on drug metabolism supported by CYP2C9.

\section{CYP2C19 Activity}

The activity of CYP2C19 was tested with both the WT and R550W variant of POR. We found that in CYP2C19 assays, the R550W variant of POR showed only 2.9\% of the WT POR activity (Figure 8B). The effect of R550W variation in POR on CYP2C19 was also severe, indicating a highly reduced capacity of drug metabolism reactions by CYP2C19.

\section{CYP3A4 Activity}

The R550W variant of POR showed only $10.2 \%$ activity in CYP3A4 assays as compared to the WTPOR enzyme (Figure 8C). The loss of activities for drug-metabolizing cytochrome P450 enzymeCYP3A4 by the POR variant R550W indicates problems with POR-P450 interactions which seem to be different for different cytochrome $\mathrm{P} 450$ partners.

\section{CYP3A5 Activity}

The R550W variant of POR had only $31.4 \%$ of the WT activity in CYP3A5 assay (Figure 8D). This was different from the results obtained for the CYP3A4 activity assays, indicating there are differences in the interaction of POR with these two closely related cytochrome P450 proteins. The effect of R550W variation in POR on CYP3A5 was not as strong as in case of CYP3A4 activity, but the loss of activity was still more than $50 \%$, indicating a reduced capacity of drug metabolism reactions mediated by CYP3A5. CYP3A5 is involved in the metabolism of tacrolimus, an immunosuppressant drug used during organ transplants which has a narrow therapeutic index.

\section{The R550W mutation in POR affects NADPH binding.}

The structural analysis of the R550W mutation indicated an effect on NADPH. We sought to examine the impact of R550W mutation in POR on the utilization of NADPH using three different assays (Figure 9, Table 4). For examining the role of NADPH concentration in reactions supported by POR, the substrate concentrations (Cytochrome c, MTT, and aromatase substrate androstenedione) were kept 
constant, and NADPH concentration was varied. In the cytochrome c reduction assay, a fivefold increase in Km for NADPH was observed for the POR-R550W compared to the WT-POR (Figure 9A). A similar effect was also observed using MTT reduction assay with a 4.8-fold increase in $\mathrm{Km}$ for NADPH for the POR-R550W compared to WT POR (Figure 9B). We also performed the CYP19A1 assay with varying concentrations of NADPH and observed a severe loss of CYP19A1 activity for the POR-R550W (Figure 9C, 10A). In the CYP19A1 assay, a direct evaluation of NADPH oxidation could not be made as the final product was the metabolism of androstenedione into estrone, but the loss of protein-protein interaction coupled with the loss of flavins in POR-R550W would severely limit the activity of CYP19A1 due to multiple interactions required for completion of one catalytic cycle. At a fixed (100 nM) substrate concentration of androstenedione, The CYP19A1 activity supported by PORR550W was only $8.5 \%$ of POR-WT (Figure 10B).

\section{Discussion}

In this report, we have investigated the cause of CYP19A1 deficiency manifested not by any changes in CYP19A1 itself but by a novel mutation in POR. A comprehensive examination of multiple cytochrome P450 enzymes encompassing both the steroid as well as drug-metabolizing activities was performed, which showed severe inhibition of multiple enzyme activities due to the R550W mutation in POR. Severe inhibition of CYP19A1 activity due to the R550W mutation in POR corroborates our previous hypothesis of both the virilization of the patient as well as maternal virilization during pregnancy due to the mutation in POR affecting CYP19A1 activity. The results described here also show that in severe cases of POR deficiency, the steroid as well as drug-metabolizing cytochrome P450 enzyme activities, that are dependent on POR, may be affected.

Remarkably, although the R550 residue is not directly involved in either the FAD or FMN binding in POR, a loss of one-third of flavin content, for both the FAD as well as FMN was observed. Previously we have shown that mutations in POR may cause protein instability which may ultimately lead to loss of flavin cofactors. A reduction in flavin content by itself does not explain the severe loss of activities of all cytochrome P450 enzymes studied. Consistent with this, some of the small molecule substrates of POR, that can be reduced through FAD (FeCN) or requiring FMN (MTT) were only moderately affected, indicating protein-protein interactions play a vital role in the overall effect of R550W mutation in POR. The CYP19A1, requiring several electron transfer steps for its metabolic reactions, is affected to a greater extent compared to activities of POR towards small-molecule substrates. The overall effects of R550W mutation on steroid metabolism may be more complicated due to inhibition of several enzyme activities including CYP17A1 and CYP21A2, both of which catalyze critical steps in human steroidogenesis $(60,61)$. 
The patient, an individual with 46, XX DSD, presented signs of prenatal aromatase deficiency as indicated from strong maternal virilization during pregnancy with highly elevated serum $\mathrm{T}$ levels at delivery that returned to normal, newborn ambiguous genitalia with elevated $\mathrm{T}$ for the female sex, and slightly elevated 17OH-P that progressively diminished. CYP19A1 gene analysis was normal, and it was not until seven years later that compound heterozygous $P O R$ gene variants were detected by using a panel of candidate genes for DSD in DNA samples from DSD patients lacking a molecular diagnosis. Clinical and biochemical control at prepubertal age (8 years) revealed normal skeletal growth, normal baseline adrenal function (cortisol and ACTH), although with an elevated 17OH-P.

The allele c.73_74delCT/p.Leu25Phefs*93 is predicted to be a null allele resulting from a premature stop codon truncated at amino acid position 93 out of 680 residues in POR protein. Therefore, the protein encoded by the c.1648C >T/p.Arg550Trp allele would be responsible for the patient's phenotype. Prenatal and neonatal phenotype predicted a severe aromatase deficiency, whereas the elevated 17-OH-P, although with normal cortisol and ACTH, may have indicated the presence of mild 21-hydroxylase and 17,20-lyase deficiencies. The mutation Arg550Trp is located in the NADPH binding region of POR. Computational analysis predicted instability in the NADPH binding region of POR by R550W mutation due to the disruption of hydrogen bonding, which may affect cytochrome P450 activities to a higher degree than small-molecule partners. Computationally predicted negative effects of R550W mutation in POR on several cytochrome P450 activities as well as binding of $\mathrm{NADPH}$, were confirmed by experiments using recombinant proteins. These results suggest a pathological effect of POR R550W and a diagnosis of PORD in the patient with p.Arg550Trp/p.Leu25PhefsTer93 in POR. The 46, XX patient and her mother presented prenatal aromatase deficiency; at prepubertal age and without steroid hormone replacement therapy growth is normal and baseline adrenal function is normal (cortisol and ACTH) although the increased level of 17OH-P demonstrates a mild 21-hydroxylase deficiency. In PORD, 46, XX neonate may be virilized at birth due to effects of prenatal androgens produced by alternate pathway $(62,63)$ but postnatal virilization may not progress before pubertal age. After birth, alternate pathway is suppressed and a sex steroid deficiency would become visible with age. Further changes may occur during puberty including hypergonadotropic hypogonadism and enlarged ovarian cysts. Due to reduced CYP19A1 activity, it is predicted that aromatase deficiency will manifest at pubertal age, most probably needing sex hormone replacement therapy and interfering with future fertility while adrenal function will need to be monitored.

An increase in steroids produced through the alternate (backdoor) pathway of biosynthesis could also be an indicator of PORD (62-66). Production of DHT from alternate pathway involving POR and CYP17A1 as well as AKR1C2 and AKR1C4 has been described in humans $(67,68)$. Lower levels of estriol in women with a PORD fetus may also cause hyperandrogenism resembling CYP19A1 
deficiency (65). Another explanation for hyperandrogenism during pregnancy is the formation of DHT from the alternate pathway, that could not be efficiently metabolized by mother $(62,64)$. Production of androgens via 17-hydroxyprogesterone (17-OH-P) through the alternate pathway has been demonstrated in neonates with P450 oxidoreductase deficiency during the first weeks of life (62). Currently, long term outcomes of patients with PORD are not available and follow-up of patients over the years may provide further details about the role of different steroid metabolites as well as the impact of prenatal exposure to DHT produced via alternate pathway in $46, \mathrm{XX}$ patients. In addition, consideration should also be given to combined effects of variations in POR as well as cytochrome P450 enzymes as demonstrated for the common polymorphism of CYP19A1 and variant forms of POR (69).

From the therapeutic perspective, supplementation with steroids is a viable and commonly used option to treat POR deficiency, especially when the loss of exact metabolites can be measured in the serum or urine of patients by use of GC-MS or other methods $(9,70,71)$. A low dose of glucocorticoid supplementation is often prescribed. The need for glucocorticoid replacement could be determined via ACTH stimulation tests. In 46, XX patients showing signs of aromatase deficiency, estrogen replacement may be needed. However, the implications of a defect in drug metabolizing enzymes observed here for POR-R550W as well as other mutations in POR need to be considered. Several hepatic drug metabolizing cytochrome P450 enzymes that show reduced activities due to mutations in POR are involved in the metabolism of both estrogens as well as androgens (e.g. CYP3A4) $(58,59,72)$. Transdermal estrogen patches are suggested as an option to bypass the effects of hepatic metabolism $(65,73)$. However, long term effect of multi steroid supplementation may have unknown side effects on normal growth and development, and therefore, an accurate characterization of individual variations in POR is required to characterize the effects of different steps in steroid metabolism and tailor the therapeutic interventions based on personalized steroid and enzyme activity profiles (74). A detailed characterization of the effects of POR mutation R550W on multiple enzymes described is a step towards this goal of personalized medicine.

\section{Acknowledgments}

This work was supported in part by grants from the Swiss National Science Foundation (31003A134926), the Novartis Foundation for Medical-Biological Research (18A053) and Burgergemeinde Bern to AVP, and from Fondo de Investigación Sanitaria, ISCIII, Spain (PI05/01647) to SB-S and MFC. 


\section{Data availability}

The datasets generated during and analyzed during the current study are not publicly available but are available from the corresponding author on reasonable request. Restrictions apply to the availability of data generated or analyzed during this study to preserve patient confidentiality or because they were used under license. The corresponding author will on request detail the restrictions and any conditions under which access to some data may be provided. 
References

1. Pandey AV, Flück CE. NADPH P450 oxidoreductase: structure, function, and pathology of diseases. Pharmacol Ther. 2013;138(2):229-254.

2. Flück CE, Tajima T, Pandey AV, Arlt W, Okuhara K, Verge CF, Jabs EW, Mendonca BB, Fujieda K, Miller WL. Mutant P450 oxidoreductase causes disordered steroidogenesis with and without Antley-Bixler syndrome. Nat Genet. 2004;36(3):228-230.

3. Peterson RE, Imperato-McGinley J, Gautier T, Shackleton CHL. Male pseudohermaphroditism due to multiple defects in steroid-biosynthetic microsomal mixed-function oxidases. A new variant of congenital adrenal hyperplasia. N Engl J Med. 1985;313(19):1182-1191.

4. Pandey AV, Fluck CE, Huang N, Tajima T, Fujieda K, Miller WL. P450 oxidoreductase deficiency: a new disorder of steroidogenesis affecting all microsomal P450 enzymes. Endocr Res. 2004;30(4):881-888.

5. Fukami M, Horikawa R, Nagai T, Tanaka T, Naiki Y, Sato N, Okuyama T, Nakai H, Soneda S, Tachibana K, Matsuo N, Sato S, Homma K, Nishimura G, Hasegawa T, Ogata T. Cytochrome P450 oxidoreductase gene mutations and Antley-Bixler syndrome with abnormal genitalia and/or impaired steroidogenesis: Molecular and clinical studies in 10 patients. $J$ Clin Endocr Metab. 2005;90(1):414-426.

6. Arlt W, Walker EA, Draper N, Ivison HE, Ride JP, Hammer F, Chalder SM, BoruckaMankiewicz M, Hauffa BP, Malunowicz EM, Stewart PM, Shackleton CH. Congenital adrenal hyperplasia caused by mutant $\mathrm{P} 450$ oxidoreductase and human androgen synthesis: analytical study. Lancet. 2004;363(9427):2128-2135.

7. Adachi M, Tachibana K, Asakura Y, Yamamoto T, Hanaki K, Oka A. Compound heterozygous mutations of cytochrome P450 oxidoreductase gene (POR) in two patients with Antley-Bixler syndrome. Am J Med Genet A. 2004;128A(4):333-339.

8. Huang N, Pandey AV, Agrawal V, Reardon W, Lapunzina PD, Mowat D, Jabs EW, Van Vliet G, Sack J, Flück CE, Miller WL. Diversity and function of mutations in p450 oxidoreductase in patients with Antley-Bixler syndrome and disordered steroidogenesis. Am J Hum Genet. 2005;76(5):729-749.

9. Krone N, Reisch N, Idkowiak J, Dhir V, Ivison HE, Hughes BA, Rose IT, O'Neil DM, Vijzelaar R, Smith MJ, MacDonald F, Cole TR, Adolphs N, Barton JS, Blair EM, Braddock SR, Collins F, Cragun DL, Dattani MT, Day R, Dougan S, Feist M, Gottschalk ME, Gregory JW, Haim M, Harrison R, Olney AH, Hauffa BP, Hindmarsh PC, Hopkin RJ, Jira PE, Kempers M, Kerstens MN, Khalifa MM, Kohler B, Maiter D, Nielsen S, O'Riordan SM, Roth CL, Shane KP, Silink M, Stikkelbroeck NMML, Sweeney E, Szarras-Czapnik M, Waterson JR, Williamson L, Hartmann MF, Taylor NF, Wudy SA, Malunowicz EM, Shackleton CHL, Arlt W. Genotype-Phenotype Analysis in Congenital Adrenal Hyperplasia due to P450 Oxidoreductase Deficiency. J Clin Endocr Metab. 2012;97(2):E257-E267.

10. Fukami M, Ogata T. Cytochrome P450 oxidoreductase deficiency: rare congenital disorder leading to skeletal malformations and steroidogenic defects. Pediatr Int. 2014;56(6):805-808.

11. Fukami M, Nishimura G, Homma K, Nagai T, Hanaki K, Uematsu A, Ishii T, Numakura C, Sawada H, Nakacho M, Kowase T, Motomura K, Haruna H, Nakamura M, Ohishi A, Adachi M, Tajima T, Hasegawa Y, Hasegawa T, Horikawa R, Fujieda K, 
Ogata T. Cytochrome P450 Oxidoreductase Deficiency: Identification and Characterization of Biallelic Mutations and Genotype-Phenotype Correlations in 35 Japanese Patients. J Clin Endocr Metab. 2009;94(5):1723-1731.

12. Lu AY, Junk KW, Coon MJ. Resolution of the cytochrome P-450-containing $\omega$ hydroxylation system of liver microsomes into three components. $J$ Biol Chem. 1969;244(13):3714-3721.

13. Murataliev MB, Feyereisen R. Interaction of NADP(H) with oxidized and reduced P450 reductase during catalysis, studies with nucleotide analogues. Biochemistry. 2000;39(17):5066-5074.

14. Masters BSS. The journey from NADPH-cytochrome P450 oxidoreductase to nitric oxide synthases. Biochemical and Biophysical Research Communications. 2005;338(1):507-519.

15. Shen AL, O'Leary KA, Kasper CB. Association of multiple developmental defects and embryonic lethality with loss of microsomal NADPH-cytochrome p450 oxidoreductase. Journal of Biological Chemistry. 2002;277(8):6536-6541.

16. Flück CE, Pandey AV. Clinical and biochemical consequences of p450 oxidoreductase deficiency. Endocr Dev. 2011;20:63-79.

17. Flück CE, Pandey AV, Huang N, Agrawal V, Miller WL. P450 oxidoreductase deficiency - a new form of congenital adrenal hyperplasia. Endocr Dev. 2008;13:6781.

18. Flück CE, Nicolo C, Pandey AV. Clinical, structural and functional implications of mutations and polymorphisms in human NADPH P450 oxidoreductase. Fund Clin Pharmacol. 2007;21(S2):399-410.

19. Agrawal V, Huang N, Miller WL. Pharmacogenetics of P450 oxidoreductase: effect of sequence variants on activities of CYP1A2 and CYP2C19. Pharmacogenet Genom. 2008;18(7):569-576.

20. Huang N, Agrawal V, Giacomini KM, Miller WL. Genetics of P450 oxidoreductase: Sequence variation in $\mathbf{8 4 2}$ individuals of four ethnicities and activities of $\mathbf{1 5}$ missense mutations. Proceedings of the National Academy of Sciences of the United States of America. 2008;105(5):1733-1738.

21. Sahakitrungruang $T$, Huang N, Tee MK, Agrawal V, Russell WE, Crock P, Murphy N, Migeon CJ, Miller WL. Clinical, genetic, and enzymatic characterization of P450 oxidoreductase deficiency in four patients. $J$ Clin Endocrinol Metab. 2009;94(12):4992-5000.

22. Agrawal V, Choi JH, Giacomini KM, Miller WL. Substrate-specific modulation of CYP3A4 activity by genetic variants of cytochrome P450 oxidoreductase. Pharmacogenet Genom. 2010;20(10):611-618.

23. Flück CE, Pandey AV. Impact on CYP19A1 activity by mutations in NADPH cytochrome P450 oxidoreductase. J Steroid Biochem Mol Biol. 2017;165(Pt A):6470.

24. Parween S, Roucher-Boulez F, Flück CE, Lienhardt-Roussie A, Mallet D, Morel Y, Pandey AV. P450 Oxidoreductase Deficiency: Loss of Activity Caused by Protein Instability From a Novel L374H Mutation. J Clin Endocrinol Metab. 2016;101(12):4789-4798.

25. Flück CE, Mallet D, Hofer G, Samara-Boustani D, Leger J, Polak M, Morel Y, Pandey AV. Deletion of P399_E401 in NADPH cytochrome P450 oxidoreductase results in 
partial mixed oxidase deficiency. Biochem Biophys Res Commun. 2011;412(4):572577.

26. Pandey AV, Kempna P, Hofer G, Mullis PE, Flück CE. Modulation of human CYP19A1 activity by mutant NADPH P450 oxidoreductase. Mol Endocrinol. 2007;21(10):25792595.

27. Burkhard FZ, Parween S, Udhane SS, Flück CE, Pandey AV. P450 Oxidoreductase deficiency: Analysis of mutations and polymorphisms. J Steroid Biochem Mol Biol. 2017;165:38-50.

28. Simpson ER, Mahendroo MS, Means GD, Kilgore MW, Hinshelwood MM, GrahamLorence S, Amarneh B, Ito Y, Fisher CR, Michael MD, et al. Aromatase cytochrome P450, the enzyme responsible for estrogen biosynthesis. Endocr Rev. 1994;15(3):342-355.

29. Bilezikian JP, Morishima A, Bell J, Grumbach MM. Increased bone mass as a result of estrogen therapy in a man with aromatase deficiency. $N$ Engl $J$ Med. 1998;339(9):599-603.

30. Rochira V, Balestrieri A, Faustini-Fustini M, Borgato S, Beck-Peccoz P, Carani C. Pituitary function in a man with congenital aromatase deficiency: effect of different doses of transdermal E2 on basal and stimulated pituitary hormones. $J$ Clin Endocrinol Metab. 2002;87:2857-2862.

31. Lin L, Ercan O, Raza J, Burren CP, Creighton SM, Auchus RJ, Dattani MT, Achermann JC. Variable phenotypes associated with aromatase (CYP19) insufficiency in humans. J Clin Endocrinol Metab. 2007;92(3):982-990.

32. Belgorosky A, Guercio G, Pepe C, Saraco N, Rivarola MA. Genetic and clinical spectrum of aromatase deficiency in infancy, childhood and adolescence. Horm Res. 2009;72(6):321-330.

33. Bulun SE, Simpson ER. Regulation of aromatase expression in human tissues. Breast cancer research and treatment. 1994;30(1):19-29.

34. Shozu M, Akasofu K, Harada T, Kubota Y. A new cause of female pseudohermaphroditism: placental aromatase deficiency. J Clin Endocrinol Metab. 1991;72(3):560-566.

35. Morishima A, Grumbach MM, Simpson ER, Fisher C, Qin K. Aromatase deficiency in male and female siblings caused by a novel mutation and the physiological role of estrogens. J Clin Endocrinol Metab. 1995;80(12):3689-3698.

36. Bouchoucha N, Samara-Boustani D, Pandey AV, Bony-Trifunovic H, Hofer G, Aigrain Y, Polak M, Flück CE. Characterization of a novel CYP19A1 (aromatase) R192H mutation causing virilization of a 46,XX newborn, undervirilization of the $46, \mathrm{XY}$ brother, but no virilization of the mother during pregnancies. Mol Cell Endocrinol. 2014;390(1-2):8-17.

37. Stocco C. Tissue physiology and pathology of aromatase. Steroids. 2012;77(1-2):2735.

38. Conte FA, Grumbach MM, Ito Y, Fisher CR, Simpson ER. A syndrome of female pseudohermaphrodism, hypergonadotropic hypogonadism, and multicystic ovaries associated with missense mutations in the gene encoding aromatase (P450arom). $J$ Clin Endocrinol Metab. 1994;78(6):1287-1292.

39. Khatri Y, Luthra A, Duggal R, Sligar SG. Kinetic solvent isotope effect in steady-state turnover by CYP19A1 suggests involvement of Compound 1 for both hydroxylation and aromatization steps. FEBS Lett. 2014;588(17):3117-3122. 
40. Akhtar M, Wright JN. Acyl-Carbon Bond Cleaving Cytochrome P450 Enzymes: CYP17A1, CYP19A1 and CYP51A1. Adv Exp Med Biol. 2015;851:107-130.

41. Fukami M, Hasegawa T, Horikawa R, Ohashi T, Nishimura G, Homma K, Ogata T. Cytochrome $\mathbf{P 4 5 0}$ oxidoreductase deficiency in three patients initially regarded as having 21-hydroxylase deficiency and/or aromatase deficiency: Diagnostic value of urine steroid hormone analysis. Pediatric Research. 2006;59(2):276-280.

42. Zanger UM, Schwab M. Cytochrome P450 enzymes in drug metabolism: regulation of gene expression, enzyme activities, and impact of genetic variation. Pharmacol Ther. 2013;138(1):103-141.

43. Meyer UA, Zanger UM, Schwab M. Omics and drug response. Annu Rev Pharmacol Toxicol. 2013;53:475-502.

44. Klein K, Zanger UM. Pharmacogenomics of Cytochrome P450 3A4: Recent Progress Toward the "Missing Heritability" Problem. Front Genet. 2013;4:12.

45. Fernandez-Cancio $M$, Viswanath $N$, Puzhankara $R$, Valiyaprambil Pavithran $P$, Mora-Palma C, Camats N, Audi L, Benito-Sanz S. A Novel Homozygous AMRH2 Gene Mutation in a Patient with Persistent Mullerian Duct Syndrome. Sex Dev. 2019;13(2):87-91.

46. Richards S, Aziz N, Bale S, Bick D, Das S, Gastier-Foster J, Grody WW, Hegde M, Lyon E, Spector E, Voelkerding K, Rehm HL, Committee ALQA. Standards and guidelines for the interpretation of sequence variants: a joint consensus recommendation of the American College of Medical Genetics and Genomics and the Association for Molecular Pathology. Genetics in medicine : official journal of the American College of Medical Genetics. 2015;17(5):405-424.

47. Nicolo C, Flück CE, Mullis PE, Pandey AV. Restoration of mutant cytochrome P450 reductase activity by external flavin. Mol Cell Endocrinol. 2010;321(2):245-252.

48. Pandey AV, Flück CE, Mullis PE. Altered heme catabolism by heme oxygenase-1 caused by mutations in human NADPH cytochrome $\mathbf{P 4 5 0}$ reductase. Biochem Biophys Res Commun. 2010;400(3):374-378.

49. Udhane SS, Parween S, Kagawa N, Pandey AV. Altered CYP19A1 and CYP3A4 Activities Due to Mutations A115V, T142A, Q153R and P284L in the Human P450 Oxidoreductase. Front Pharmacol. 2017;8:580.

50. Guengerich FP, Martin MV, Sohl CD, Cheng Q. Measurement of cytochrome P450 and NADPH-cytochrome P450 reductase. Nature protocols. 2009;4(9):1245-1251.

51. Yim SK, Yun CH, Ahn T, Jung HC, Pan JG. A continuous spectrophotometric assay for NADPH-cytochrome $\mathbf{P 4 5 0}$ reductase activity using 3-(4,5-dimethylthiazol-2-yl)-2,5diphenyltetrazolium bromide. J Biochem Mol Biol. 2005;38(3):366-369.

52. Marohnic CC, Panda SP, McCammon K, Rueff J, Masters BSS, Kranendonk M. Human Cytochrome P450 Oxidoreductase Deficiency Caused by the Y181D Mutation: Molecular Consequences and Rescue of Defect. Drug Metabolism and Disposition. 2010;38(2):332-340.

53. Faeder EJ, Siegel LM. A rapid micromethod for determination of FMN and FAD in mixtures. Anal Biochem. 1973;53(1):332-336.

54. Kagawa N. Efficient expression of human aromatase (CYP19) in E. coli. Methods Mol Biol. 2011;705:109-122.

55. Fernandez-Cancio M, Camats N, Fluck CE, Zalewski A, Dick B, Frey BM, Monne R, Toran N, Audi L, Pandey AV. Mechanism of the Dual Activities of Human CYP17A1 
and Binding to Anti-Prostate Cancer Drug Abiraterone Revealed by a Novel V366M Mutation Causing 17,20 Lyase Deficiency. Pharmaceuticals. 2018;11(2).

56. Pandey AV, Miller WL. Regulation of 17,20 lyase activity by cytochrome b5 and by serine phosphorylation of P450c17. J Biol Chem. 2005;280(14):13265-13271.

57. Lephart ED, Simpson ER. Assay of aromatase activity. Methods Enzymol. 1991;206:477-483.

58. Velazquez MNR, Parween S, Udhane SS, Pandey AV. Variability in human drug metabolizing cytochrome P450 CYP2C9, CYP2C19 and CYP3A5 activities caused by genetic variations in cytochrome P450 oxidoreductase. Biochem Biophys Res Commun. 2019;515(1):133-138.

59. Flück CE, Mullis PE, Pandey AV. Reduction in hepatic drug metabolizing CYP3A4 activities caused by $\mathrm{P} 450$ oxidoreductase mutations identified in patients with disordered steroid metabolism. Biochem Biophys Res Commun. 2010;401(1):149153.

60. Miller WL. Minireview: regulation of steroidogenesis by electron transfer. Endocrinology. 2005;146(6):2544-2550.

61. Scott RR, Gomes LG, Huang N, Van Vliet G, Miller WL. Apparent manifesting heterozygosity in P450 oxidoreductase deficiency and its effect on coexisting 21hydroxylase deficiency. J Clin Endocrinol Metab. 2007;92(6):2318-2322.

62. Reisch N, Taylor AE, Nogueira EF, Asby DJ, Dhir V, Berry A, Krone N, Auchus RJ, Shackleton CHL, Hanley NA, Arlt W. Alternative pathway androgen biosynthesis and human fetal female virilization. Proc Natl Acad Sci U S A. 2019;116(44):2229422299.

63. Homma K, Hasegawa T, Nagai T, Adachi M, Horikawa R, Fujiwara I, Tajima T, Takeda R, Fukami M, Ogata T. Urine steroid hormone profile analysis in cytochrome P450 oxidoreductase deficiency: Implication for the backdoor pathway to dihydrotestosterone. J Clin Endocr Metab. 2006;91(7):2643-2649.

64. Miller WL, Auchus RJ. The "backdoor pathway" of androgen synthesis in human male sexual development. PLoS Biol. 2019;17(4):e3000198.

65. Baronio F, Ortolano R, Menabò S, Cassio A, Baldazzi L, Di Natale V, Tonti G, Vestrucci B, Balsamo A. 46,XX DSD due to Androgen Excess in Monogenic Disorders of Steroidogenesis: Genetic, Biochemical, and Clinical Features. International Journal of Molecular Sciences. 2019;20(18):4605.

66. Fukami M, Homma K, Hasegawa T, Ogata T. Backdoor pathway for dihydrotestosterone biosynthesis: implications for normal and abnormal human sex development. Dev Dyn. 2013;242(4):320-329.

67. Flück CE, Meyer-Boni M, Pandey AV, Kempna P, Miller WL, Schoenle EJ, BiasonLauber A. Why boys will be boys: two pathways of fetal testicular androgen biosynthesis are needed for male sexual differentiation. Am J Hum Genet. 2011;89(2):201-218.

68. Biason-Lauber A, Miller WL, Pandey AV, Flück CE. Of marsupials and men: "Backdoor" dihydrotestosterone synthesis in male sexual differentiation. Mol Cell Endocrinol. 2013;371(1-2):124-132.

69. Parween S, DiNardo G, Baj F, Zhang C, Gilardi G, Pandey AV. Differential effects of variations in human P450 oxidoreductase on the aromatase activity of CYP19A1 polymorphisms R264C and R264H. The Journal of Steroid Biochemistry and Molecular Biology. 2020;196:105507. 
70. Shackleton C, Pozo OJ, Marcos J. GC/MS in Recent Years Has Defined the Normal and Clinically Disordered Steroidome: Will It Soon Be Surpassed by LC/Tandem MS in This Role? Journal of the Endocrine Society. 2018;2(8):974-996.

71. Wudy SA, Schuler G, Sánchez-Guijo A, Hartmann MF. The art of measuring steroids: Principles and practice of current hormonal steroid analysis. The Journal of Steroid Biochemistry and Molecular Biology. 2018;179:88-103.

72. Parween S, Rojas Velazquez MN, Udhane SS, Kagawa N, Pandey AV. Variability in Loss of Multiple Enzyme Activities Due to the Human Genetic Variation P284T Located in the Flexible Hinge Region of NADPH Cytochrome P450 Oxidoreductase. Frontiers in Pharmacology. 2019;10(1187).

73. Rochira V, Carani C. Aromatase deficiency in men: a clinical perspective. Nature Reviews Endocrinology. 2009;5(10):559-568.

74. Flück CE, Pandey AV. Human P450 Oxidoreductase Deficiency. In: Huhtaniemi I, Martini L, eds. Encyclopedia of Endocrine Diseases (Second Edition). Oxford: Academic Press; 2019:431-443. 


\section{Figure Legends}

Figure 1. Role of POR in supporting the activities of drug and steroid metabolizing cytochrome P450 enzymes. POR is a flavoprotein containing co-factors FAD and FMN. Cytochrome P450 proteins found in endoplasmic reticulum metabolize a wide range of molecules, including steroid hormones and drugs. Energy requirements for the metabolic reactions of cytochrome P450 located in the endoplasmic reticulum are provided by NADPH. POR binds NADPH and undergoes conformation changes to transfer electrons from NADPH to FMN via FAD. Interaction of POR with P450 proteins results in further electron transfer from FMN bound to POR to the heme group of cytochrome P450. In this metabolic process, NADPH is reduced by POR to form NADP ${ }^{+}$.

Figure 2. Role of POR in steroid and drug metabolism. POR is necessary for the metabolic activities of cytochrome $\mathrm{P} 450$ proteins located in the endoplasmic reticulum. These include the steroid metabolizing cytochromes P450 CYP17A1, CYP21A2, CYP19A1, CYP51A1 and CYP26B1 as well as drug metabolizing cytochromes P450 CYP3A4, CYP3A5, CYP2D6, CYP2C9 and CYP2C19. A reduction in POR activity may lead to loss of both the steroid as well as drug metabolizing activities. Further considerations might be required during steroid supplementation for the treatment of PORD as drug metabolizing enzymes like CYP3A4 can also cause hepatic metabolism of estrogens and androgens, and altered activities of some of these hepatic cytochrome P450 enzymes may complicate the dose requirements for steroid supplements.

\section{Figure 3: Family tree and genetic analysis of POR sequences.}

The DNA samples were analyzed with a custom-designed targeted Disorders of Sexual Development NGS panel (DSDSeq.V1, 111 genes, and three regulatory regions) using SeqCap EZ technology (Roche Nimblegen) and sequenced on a NextSeq (Illumina) platform. Sequence variations retained as candidates were verified by Sanger sequencing and DNA from parents were also analyzed as controls. (A) Compound heterozygous variants within the POR gene were identified in the proband (II-1): c.73_74delCT (p.Leu25Phefs*93) located in exon 2, inherited from the mother (I-2), and a second variant c. 1648C > T (p.Arg550Trp) in exon 13, inherited from the father (I-1). Parents are both carriers for each variant, and her brother (II-2) is a carrier for c.1648C > T (p.Arg550Trp). The arrow indicates the proband. $\mathrm{N}$ indicates normal allele. (B) Chromatogram of the variants in the POR gene (NM_000941) in this family. The arrows indicate the variant location.

Figure 4: Structural analysis of POR-R550W. (A). Location of R550W residue in POR. (B) R550 is not directly at the surface of POR. (C) Arginine 550 forms hydrogen bonds with threonine 529 to stabilize the NADPH binding domain. Its mutation to tryptophan results in destabilization of the POR structure. 
Figure 5: Flavin content of POR-WT and POR-R550W. Flavin content of the POR proteins was analyzed by boiling the proteins under selective $\mathrm{pH}$ conditions. Relative fluorescence unit (RFU) of the flavins released from the POR variants measured at (A) pH 7.7 (FMN or $\mathrm{F}_{7.7}$ ) and (B) pH 2.6 (FAD or $\left.F_{2.6}\right)$ are shown. The RFU of WT POR was fixed as a hundred percent. Data are shown as mean \pm SEM of two experiments done in triplicates.

Figure 6: Cytochrome c, MTT, and Ferricyanide reduction assay with POR-WT and PORR550W. (A) Cytochrome c (B) MTT (C) ferricyanide reduction assays were performed with the WT and POR-R550W variant. Kinetic assays were performed by monitoring the changes in absorbance at $550 \mathrm{~nm}$ for cytochrome c, $610 \mathrm{~nm}$ for MTT, and $420 \mathrm{~nm}$ for ferricyanide reduction. Data were fitted to the Michaelis-Menten kinetics model and analyzed using GraphPad Prism. The calculated Km and Vmax values are presented in Table 1. Data are shown as mean \pm SEM of three independent replicates.

Figure 7: Enzymatic activities of steroid metabolizing cytochrome P450 supported by POR-WT or POR-R550W. A. Enzymatic activity of CYP17A1 supported by POR-WT and POR-R550W. Purified, recombinant CYP17A1 and enriched bacterial membranes containing POR proteins were reconstituted, and their activity to convert $\left[{ }^{14} \mathrm{C}\right]$ labeled Progesterone into $17 \mathrm{OH}$-progesterone was tested by TLC and phosphorimager analysis. Data were analyzed using the Michaelis-Menten kinetics with GraphPad Prism. The calculated Km and Vmax values are shown in Table 3. B. Enzymatic activity of CYP21A2 supported by POR-WT and POR-R550W. The in-vitro reconstituted system was prepared by mixing purified CYP21A2, and bacterial membranes containing POR proteins and their activity to convert $\left[{ }^{14} \mathrm{C}\right]$ labeled Progesterone to $21 \mathrm{OH}$-Progesterone was measured by TLC and phosphorimager analysis. Data were analyzed using the Michaelis-Menten kinetics with GraphPad Prism. The calculated $\mathrm{Km}$ and Vmax values are shown in Table 3. C. Enzymatic activity of CYP19A1 supported by PORWT and POR-R550W. Bacterially expressed, purified, recombinant CYP19A1, and the enriched bacterial membranes containing POR proteins were mixed, and their activity to convert $\left[{ }^{3} \mathrm{H}\right]$ labeled androstenedione to estrone was tested by the tritiated water release assay. Data were analyzed using the Michaelis-Menten kinetics with GraphPad Prism. The calculated Km and Vmax values are shown in Table 3. Data are shown as mean \pm SEM of two independent replicates.

Figure 8: Activities of drug-metabolizing cytochromes P450 supported by POR-WT or PORR550W. A. Activity of cytochrome P450 CYP2C9 supported by POR-WT and POR-R550W. Assay of CYP2C9 activity was performed to compare POR-WT and POR-R550W by using $20 \mu \mathrm{M}$ BOMCC as a substrate. Activity with the WT POR was fixed as a hundred percent, and results are given as a percentage of WT activity. Data are shown as mean \pm SEM from two experiments performed in 
triplicates. B. The activity of cytochrome P450 CYP2C19 supported by POR-WT and POR-R550W. Assay of CYP2C19 activity was performed to compare POR-WT and POR-R550W by using $20 \mu \mathrm{M}$ EOMCC as a substrate. Activity with the WT POR was fixed as a hundred percent, and results are given as a percentage of WT activity. Data are shown as mean \pm SEM from two experiments performed in triplicates. C. The activity of cytochrome P450 CYP3A4 supported by POR-WT and POR-R550W. Assay of CYP3A4 activity was performed to compare POR-WT and POR-R550W by using $20 \mu \mathrm{M}$ BOMCC as a substrate. Activity with the WT POR was fixed as a hundred percent, and results are given as a percentage of WT activity. Data are shown as mean \pm SEM from two experiments performed in triplicates. D. The activity of cytochrome P450 CYP3A5 supported by POR-WT and POR-R550W. Assay of CYP3A5 activity was performed to compare POR-WT and POR-R550W by using BOMCC as a substrate. Activity with the WT POR was fixed as a hundred percent, and results are given as a percentage of WT activity. Data are shown as mean \pm SEM from two experiments performed in triplicates.

Figure 9: Co-factor dependence of R550W mutation in POR. Since the R550 residue is located near the NADPH binding site in POR, we sought to examine the role of NADPH variation and binding to R550W-POR. A. Assay of cytochrome c reduction activity with increasing NADPH concentration. In R550W-POR affinity for NADPH was diminished as indicated by a fivefold increase in KM for NADPH. B. Assay of MTT reduction activity with increasing NADPH concentration. Affinity for R550W-POR was also found to be lower as deduced from more than fourfold increase in $\mathrm{Km}$ for NADPH compared to WT-POR. C. CYP19A1 assay with increasing concentrations of NADPH. The POR-R550W showed a severe loss of activity in the CYP19A1 assay. In the CYP19A1 assays with varying NADPH concentration, the activity using the POR-R550W was too low to allow a reliable estimation of kinetic parameters, and reaction being monitored was a couple assay (aromatase activity using androstedione), therefore, calculation of kinetic parameters for NADPH reduction were not made. Data are shown as mean \pm SEM of three independent replicates.

Figure 10: Decrease in CYP19A1 activity due to POR-R550W mutation in POR. A. A bar chart showing CYP19A1 activity supported by POR-WT and POR-R550W at different concentrations of NADPH. The POR-R550W showed a severe loss of activity in the CYP19A1 assays. B. CYP19A1 activity using $100 \mathrm{nM}$ androstedione as substrate. The activity supported by R550-W variant of POR was only $8.5 \%$ of the activity with the POR-WT. Data are shown as mean \pm SEM of three independent replicates. 
Table 1. Hormone analyses of the patient and her mother. ACTH: adrenocorticotropic hormone (pg/ml); DHEA-S: dehydroepiandrosterone sulphate $(\mu \mathrm{g} / \mathrm{dL})$; 17-OH-P: 17-hydroxy-progesterone $(\mathrm{ng} / \mathrm{dL})$; cortisol $(\mu \mathrm{g} / \mathrm{dL}) ; \mathrm{T}$ : testosterone (ng/dL); E2: estradiol (ng/dL).

\begin{tabular}{|c|c|c|c|c|c|c|}
\hline & ACTH & DHEA-S & $17-\mathrm{OH}-\mathrm{P}$ & Cortisol & $\mathrm{T}$ & E2 \\
\hline & $\mathrm{pg} / \mathrm{ml}$ & $\mu \mathrm{g} / \mathrm{dL}$ & $\mathrm{ng} / \mathrm{dL}$ & $\mu \mathrm{g} / \mathrm{dL}$ & $\mathrm{ng} / \mathrm{dL}$ & $\mathrm{ng} / \mathrm{dL}$ \\
\hline Mother $\left(5^{\text {th }}\right.$ day post-partum $)$ & & 167.4 & 150 & & 545 & 11.1 \\
\hline $\begin{array}{l}\text { Mother }\left(4^{\text {th }} \text { month post- }\right. \\
\text { partum) }\end{array}$ & & & & & 26 & \\
\hline $\begin{array}{l}\text { Normal values (women: } \\
\text { follicular phase) }\end{array}$ & & $98.8-340.0$ & $19-182$ & & $6-82$ & $1.2-16.6$ \\
\hline Patient (7 days) & & & 4,700 & & 84 & \\
\hline Patient (19 days) & & & 2,100 & & 36 & \\
\hline Patient (1 month 4 days) & & & 2,400 & & 29 & \\
\hline Patient (1 month 18 days) & & & 1,510 & & 17 & \\
\hline Patient (7 months) & & $\nabla$ & 590 & & 2 & \\
\hline Patient $(8$ years $)$ & 65.2 & 47.1 & 10,400 & 14.3 & $<7$ & \\
\hline Normal values ( 8 years) & $7.2-63.3$ & $2.8-85.2$ & $7-56$ & $6.0-18.4$ & $3-32$ & \\
\hline
\end{tabular}


Table 2: Population distribution of POR variations reported in this study.

\begin{tabular}{|c|c|c|c|c|c|c|}
\hline POR & DBSNP id & Study & Population & $\begin{array}{l}\text { Sample } \\
\text { size }\end{array}$ & Ref Allele & Alt Allele \\
\hline \multirow[t]{9}{*}{ R550W } & rs782551896 & & & & & \\
\hline & & TopMed & Global & 125568 & $\mathrm{C}=0.99996$ & $T=0.00004$ \\
\hline & & $\begin{array}{l}\text { gnomAD- } \\
\text { Exomes }\end{array}$ & Global & 171252 & $\mathrm{C}=0.99995$ & $T=0.00005$ \\
\hline & & $\begin{array}{l}\text { gnomAD- } \\
\text { Exomes }\end{array}$ & European & 87224 & $\mathrm{C}=0.9999$ & $\mathrm{~T}=\mathbf{0 . 0 0 0 1}$ \\
\hline & & $\begin{array}{l}\text { gnomAD- } \\
\text { Exomes }\end{array}$ & Asian & 35462 & $C=1.000$ & $\mathrm{~T}=0.000$ \\
\hline & & $\begin{array}{l}\text { gnomAD- } \\
\text { Exomes }\end{array}$ & American & 26414 & $\mathrm{C}=0.9999$ & $\mathbf{T}=\mathbf{0 . 0 0 0 1}$ \\
\hline & & $\begin{array}{l}\text { gnomAD- } \\
\text { Exomes }\end{array}$ & African & 9698 & $\mathrm{C}=1.000$ & $\mathrm{~T}=0.000$ \\
\hline & & & $\begin{array}{l}\text { Ashkenazi } \\
\text { Jewish }\end{array}$ & 7850 & $\mathrm{C}=1.000$ & $\mathrm{~T}=0.000$ \\
\hline & & $\begin{array}{l}\text { gnomAD- } \\
\text { Exomes }\end{array}$ & Other & 4604 & $\mathrm{C}=1.00$ & $\mathrm{~T}=0.00$ \\
\hline \multirow[t]{2}{*}{ R550Q } & rs1320059073 & t & & & & \\
\hline & & TopMed & Global & 125568 & $\mathrm{G}=0.99993$ & $\mathrm{~A}=0.00007$ \\
\hline \multirow{4}{*}{$\begin{array}{l}\text { L25Pfs* } \\
93\end{array}$} & rs782696006 & & & & & \\
\hline & & TopMed & Global & 125568 & & delCT $=0.00001$ \\
\hline & & $\begin{array}{l}\text { gnomAD- } \\
\text { Exomes }\end{array}$ & Global & 246148 & & $\operatorname{delCT}=0.00001$ \\
\hline & & $\begin{array}{l}\text { gnomAD- } \\
\text { Exomes }\end{array}$ & American & 34162 & & $\operatorname{delCT}=\mathbf{0 . 0 0 0 1}$ \\
\hline
\end{tabular}


Table 3: Kinetic parameters for activities of cytochrome c, MTT, ferricyanide reduction, and CYP17A1, CYP21A2 and CYP19A1 activities supported by POR-WT and POR-R550W. For the cytochrome c, MTT and Ferricyanide reduction assay, the NADPH concentration was fixed at $100 \mu \mathrm{M}$ and varying concentrations of the substrate were used for the analysis. For the conversion of androstenedione to estrone (CYP19A1 activity), NADPH was fixed at $1 \mathrm{mM}$, and variable concentrations (10-1000 nM) of androstenedione were used. For the conversion of Progesterone to 17OH Progesterone (CYP17A1 activity) or Progesterone to 21OH Progesterone (CYP21A2 activity), NADPH was fixed at $2 \mathrm{mM}$, and variable concentrations $(0.3-5 \mu \mathrm{M})$ of Progesterone were used. Data are shown as mean \pm SEM of independent replicates ( $n=3$ for small molecule reduction assays and $n=2$ for CYP assays).

\begin{tabular}{|c|c|c|c|c|}
\hline & $\begin{array}{c}\text { Vmax } \\
\mu \mathrm{mol} / \mathrm{min} / \mathrm{mg}\end{array}$ & $\begin{array}{l}\mathbf{K m}, \\
(\mu \mathrm{M})\end{array}$ & Vmax/Km & $\% \mathrm{WT}$ \\
\hline \multicolumn{5}{|c|}{ Cytochrome c reduction assay } \\
\hline POR-WT & $873 \pm 68$ & $23.7 \pm 3.7$ & 36.8 & 100 \\
\hline POR-R550W & $267 \pm 30$ & $17.8 \pm 4.3$ & 15 & 40.8 \\
\hline \multicolumn{5}{|c|}{ MTT reduction assay } \\
\hline POR-WT & $1254 \pm 23$ & $21.3 \pm 1.5$ & 58.9 & 100 \\
\hline POR-R550W & $916 \pm 24$ & $201 \pm 11.7$ & 4.6 & 7.7 \\
\hline \multicolumn{5}{|c|}{ Ferricyanide reduction assay } \\
\hline POR-WT & $3890 \pm 88$ & $27.2 \pm 2.3$ & 143 & 100 \\
\hline \multirow[t]{2}{*}{ POR-R550W } & $2939 \pm 712$ & $74.8 \pm 54$ & 39.3 & 27.5 \\
\hline & $\begin{array}{c}\text { Vmax } \\
\text { pmol/hr/pmol } \\
\text { P450 }\end{array}$ & $\mathbf{K m}(\mu \mathbf{M})$ & Vmax/Km & $\%$ WT \\
\hline \multicolumn{5}{|c|}{ CYP19A1; aromatase (androstenedione to estrone) } \\
\hline POR-WT & $0.042 \pm 0.003$ & $0.24 \pm 0.05$ & 0.173 & 100 \\
\hline POR-R550W & $0.007 \pm 0.002$ & $0.15 \pm 0.17$ & 0.044 & 25.1 \\
\hline \multicolumn{5}{|c|}{ CYP17A1; (Progesterone to 17OH-Progesterone) } \\
\hline POR-WT & $8.2 \pm 0.47$ & $1.3 \pm 0.22$ & 6.2 & 100 \\
\hline POR-R550W & $0.3 \pm 0.004$ & $1.3 \pm 0.5$ & 0.2 & 3.4 \\
\hline \multicolumn{5}{|c|}{ CYP21A2; (Progesterone to 21OH-Progesterone) } \\
\hline POR-WT & $32.5 \pm 7.9$ & $2.2 \pm 1.28$ & 14.8 & 100 \\
\hline POR-R550W & $0.62 \pm 0.08$ & $1.33 \pm 0.5$ & 0.5 & 3.2 \\
\hline
\end{tabular}


Table 4: Effect of NADPH variation on activities supported by POR-WT and POR-R550W. To measure the effect of NADPH variation on activities of POR-WT and POR-R550W activities were measured using fixed concentrations of cytochrome c $(40 \mu \mathrm{M})$, MTT $(500 \mu \mathrm{M})$ and androstenedione $(100 \mathrm{nM})$ while the NADPH concentrations in the assays were varied from 0 to $1000 \mu \mathrm{M}$. Data are shown as mean \pm SEM of independent replicates $(n=3)$. In the assay of CYP19A1 activity with variable NADPH, the activity of CYP19A1 supported by POR-R550W was too low for kinetic parameters to be calculated with reliability. For CYP19A1 assay, "nd" indicates activity too low compared with background to be measured reliably.

\begin{tabular}{lcccc}
\hline & \multicolumn{1}{l}{$\begin{array}{c}\text { Vmax } \\
\boldsymbol{\mu m o l} / \mathbf{m i n} / \mathbf{m g}\end{array}$} & $\begin{array}{c}\mathbf{K m} \\
(\boldsymbol{\mu} \mathbf{M})\end{array}$ & $\begin{array}{c}\text { Vmax } \\
/ \mathbf{K m}\end{array}$ & \% WT \\
\hline $\begin{array}{l}\text { Cytochrome c reduction } \\
\text { POR-WT }\end{array}$ & $611.8 \pm 14$ & $8 \pm 0.7$ & 76.1 & 100 \\
POR-R550W & $434 \pm 33.6$ & $30.4 \pm 5.7$ & 14.3 & 18.8 \\
& & & & \\
MTT reduction & & & & \\
POR-WT & $994.1 \pm 58$ & $12.3 \pm 2.3$ & 81 & 100 \\
POR-R550W & $950.1 \pm 52$ & $58.4 \pm 6.3$ & 16 & 20 \\
& $\mathbf{p m o l} / \mathbf{m i n} / \mathbf{n m o l}$ & & & \\
CYP19A1 (Androstenedione to Estrone) & $\mathbf{P 4 5 0}$ & & & \\
POR-WT & $0.13 \pm 0.003$ & $11.3 \pm 3.4$ & 0.011 & 100 \\
POR-R550W & nd & nd & nd & nd \\
\hline
\end{tabular}


Figure 1

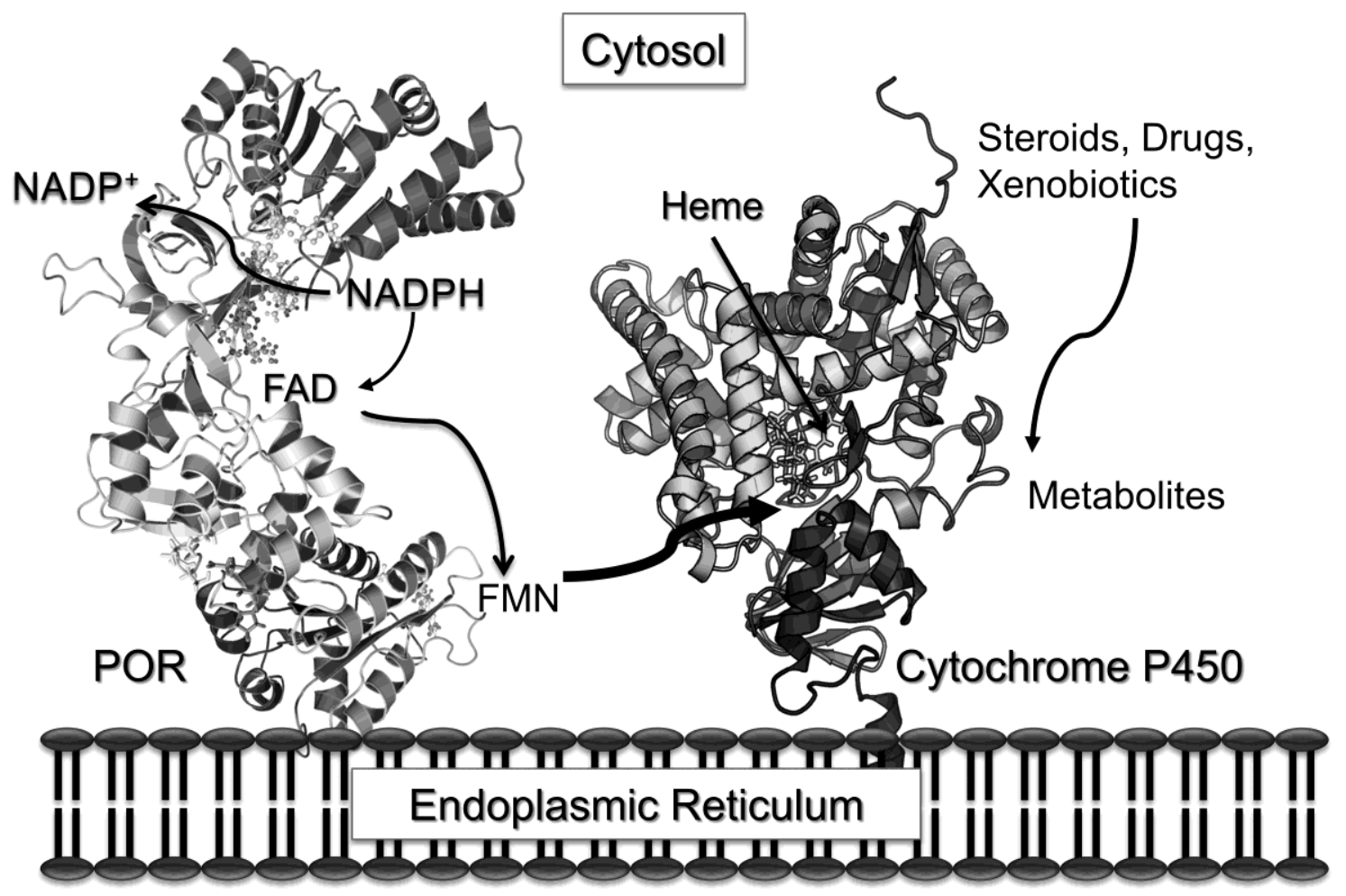


Figure 2

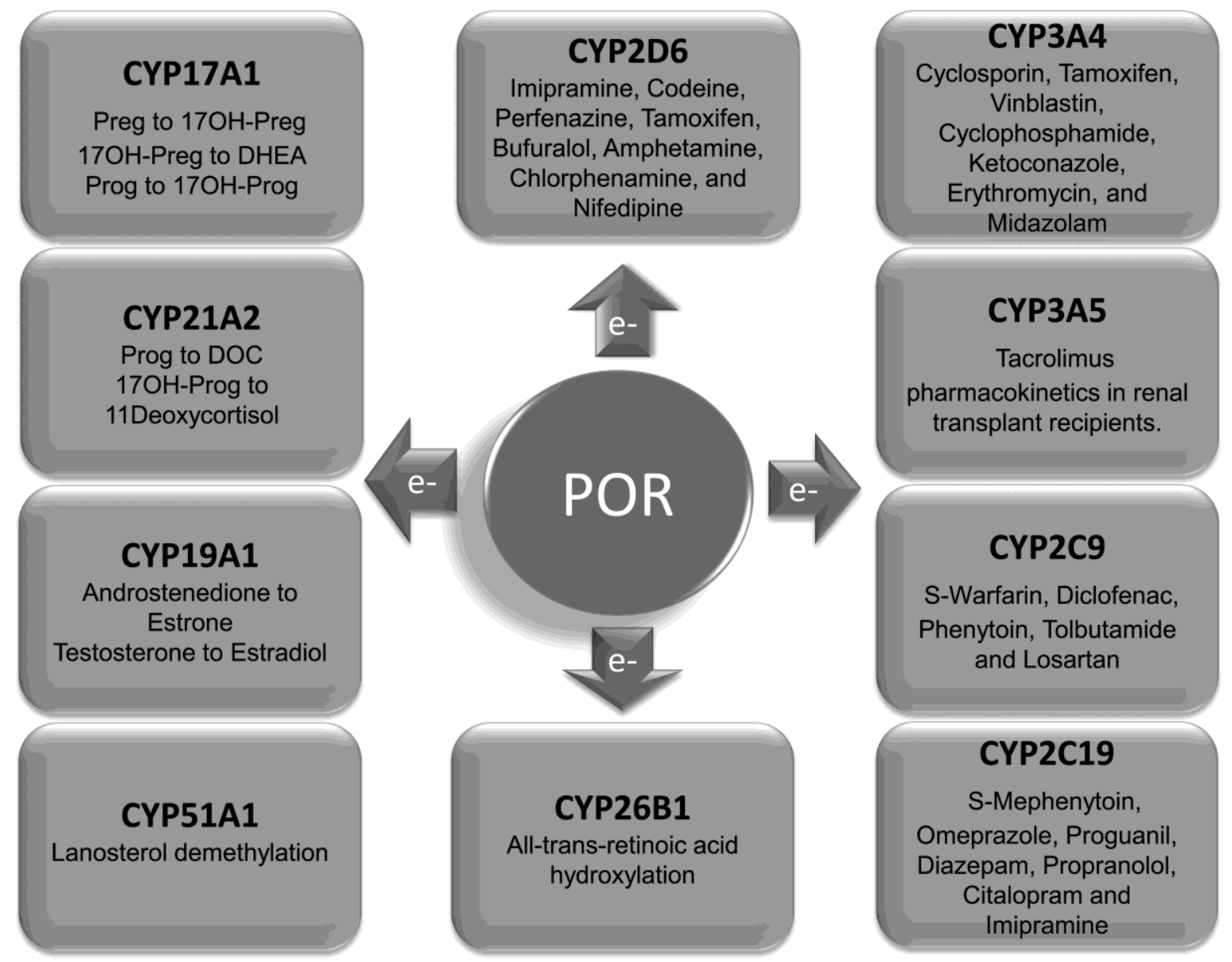




\section{Figure 3}

A

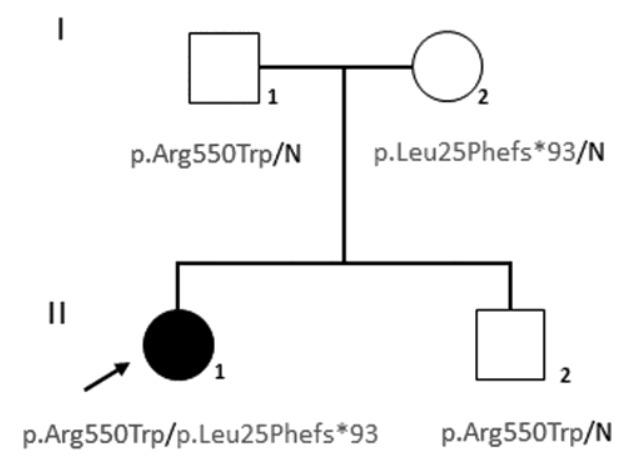

B

Father (I-1)


Figure 4
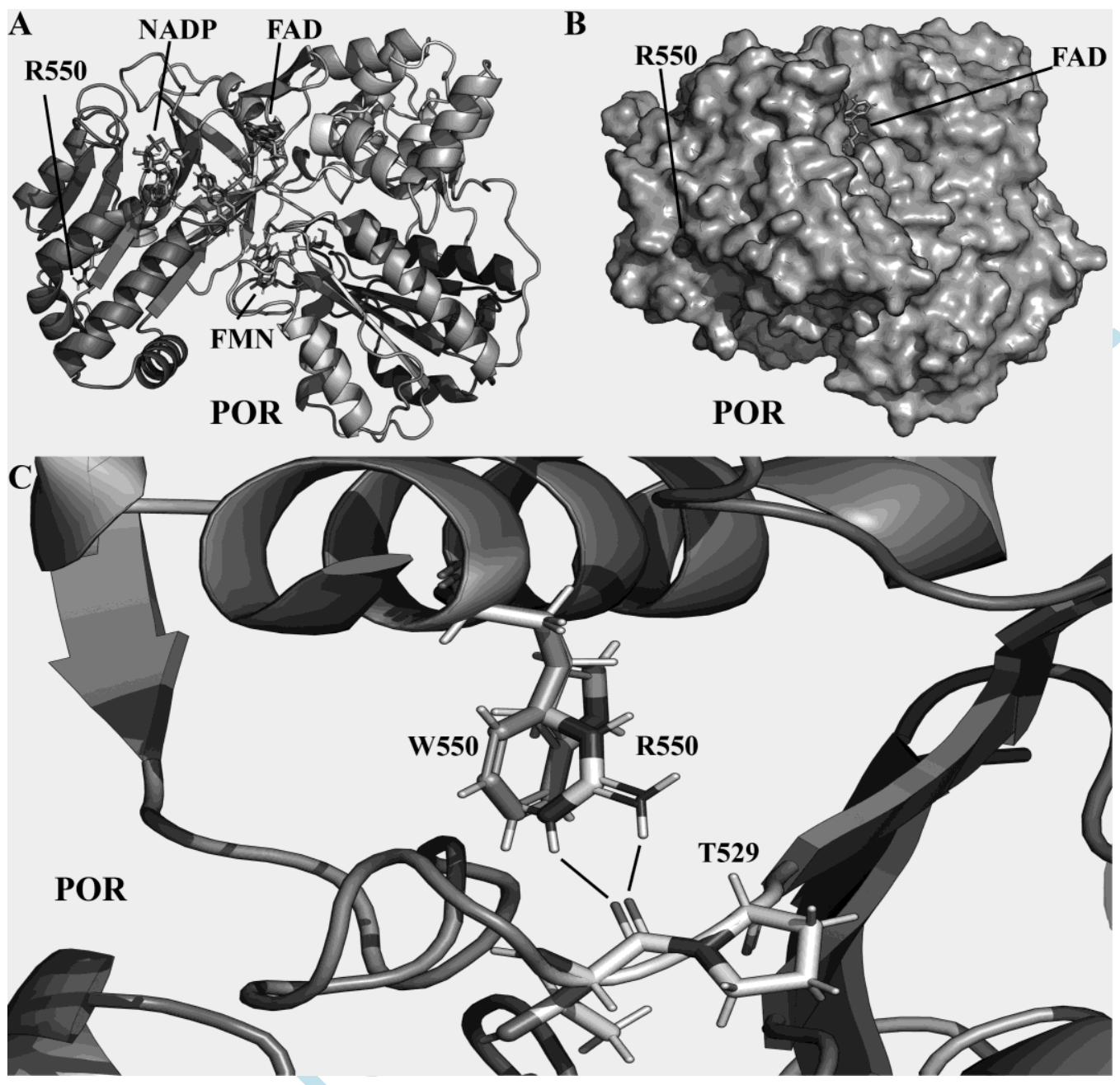
Figure 5

Figure 6

A

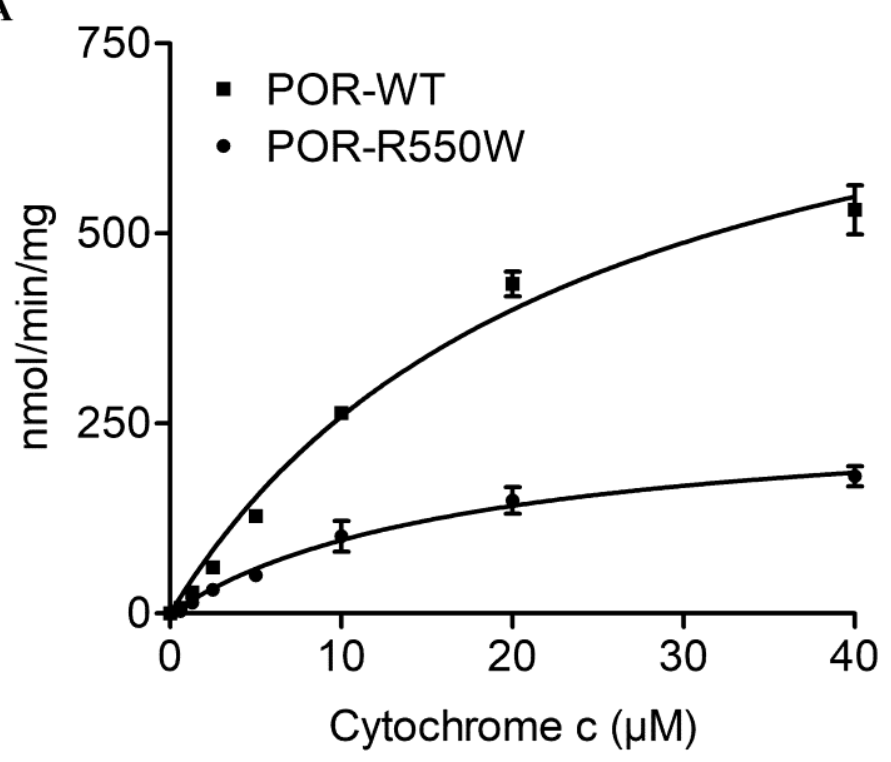

B

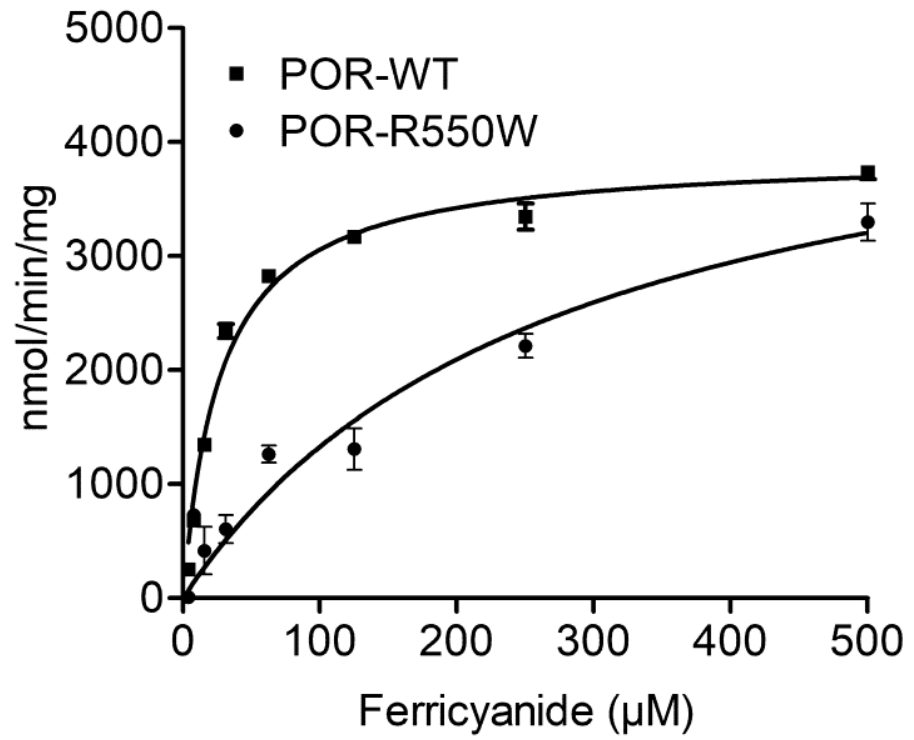

C

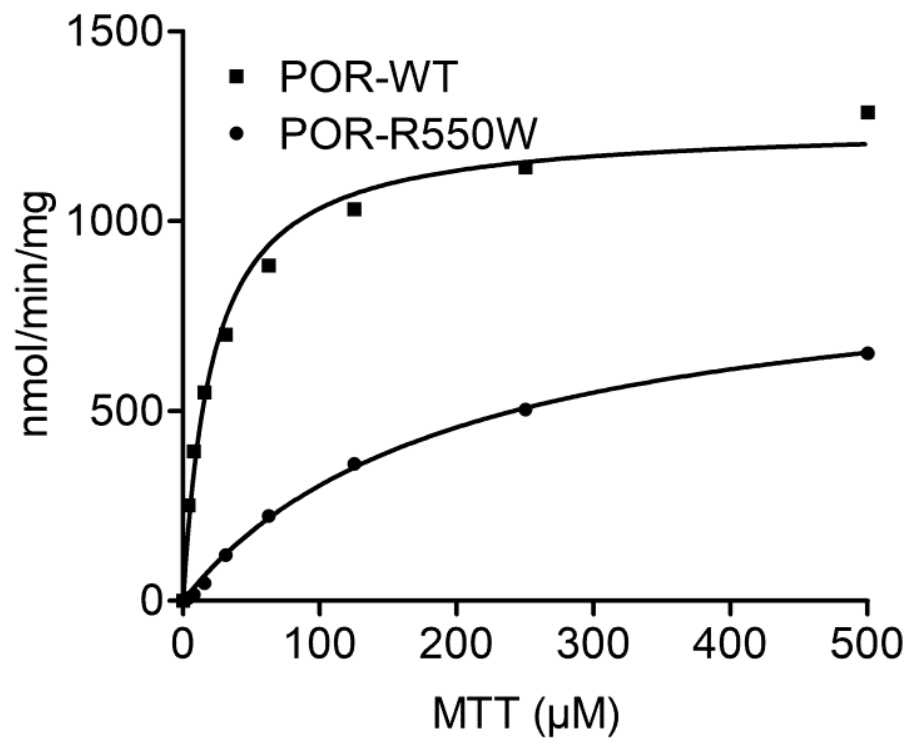


Figure 7

A

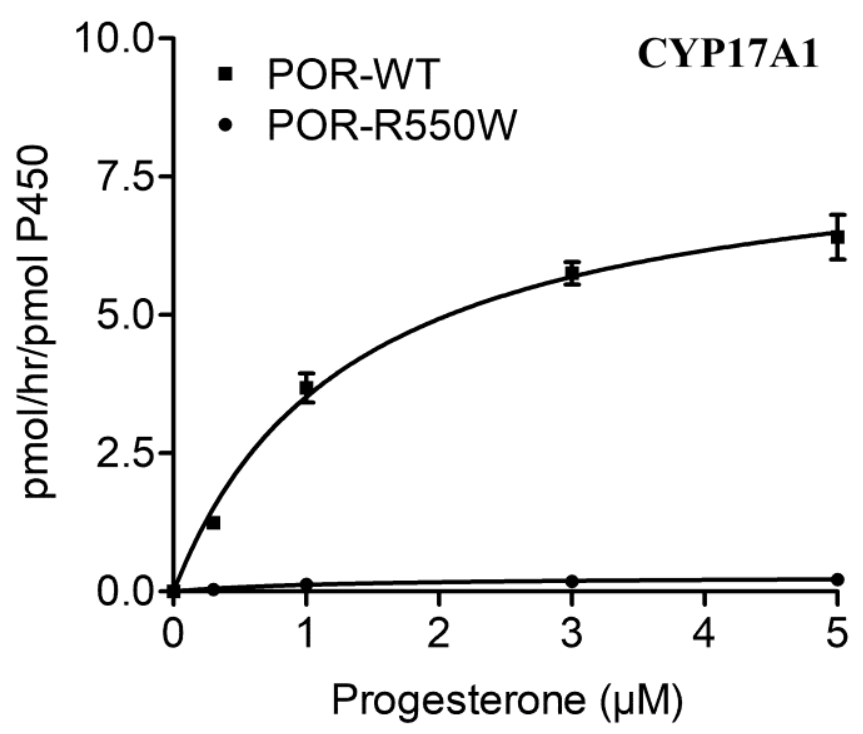

B

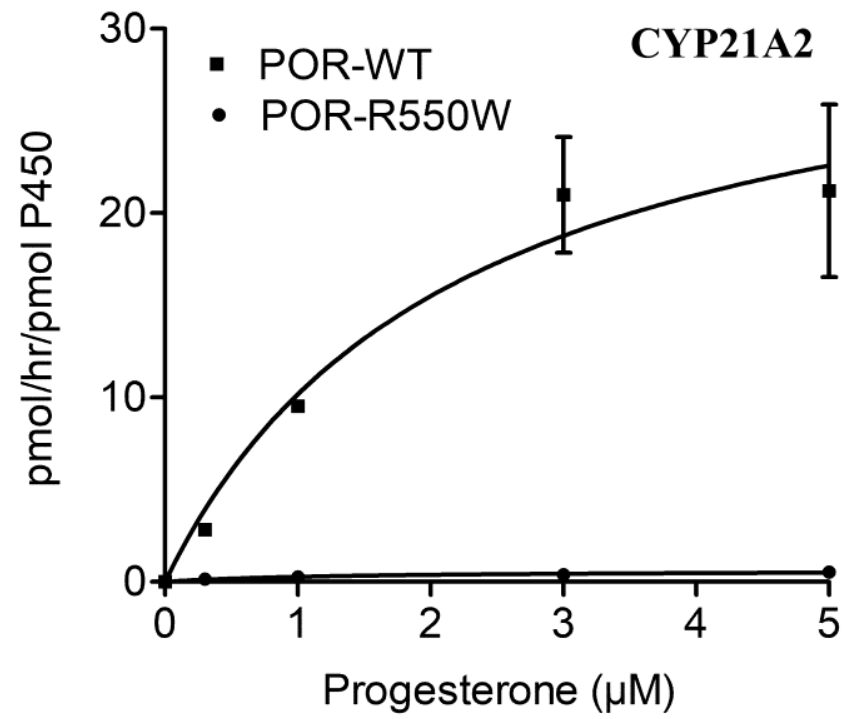

C

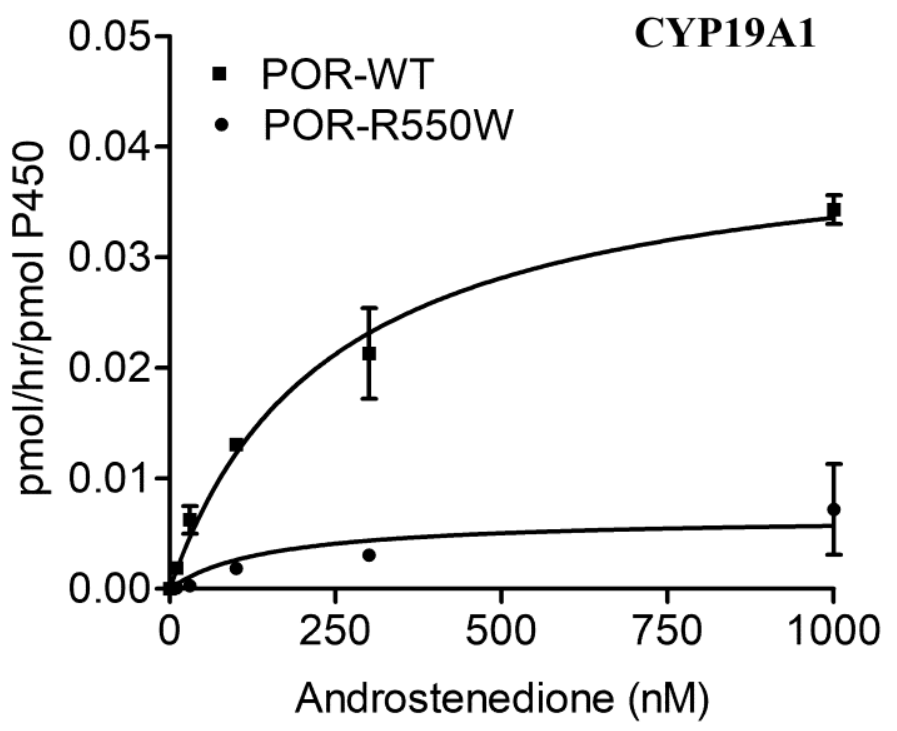


Figure 8

A
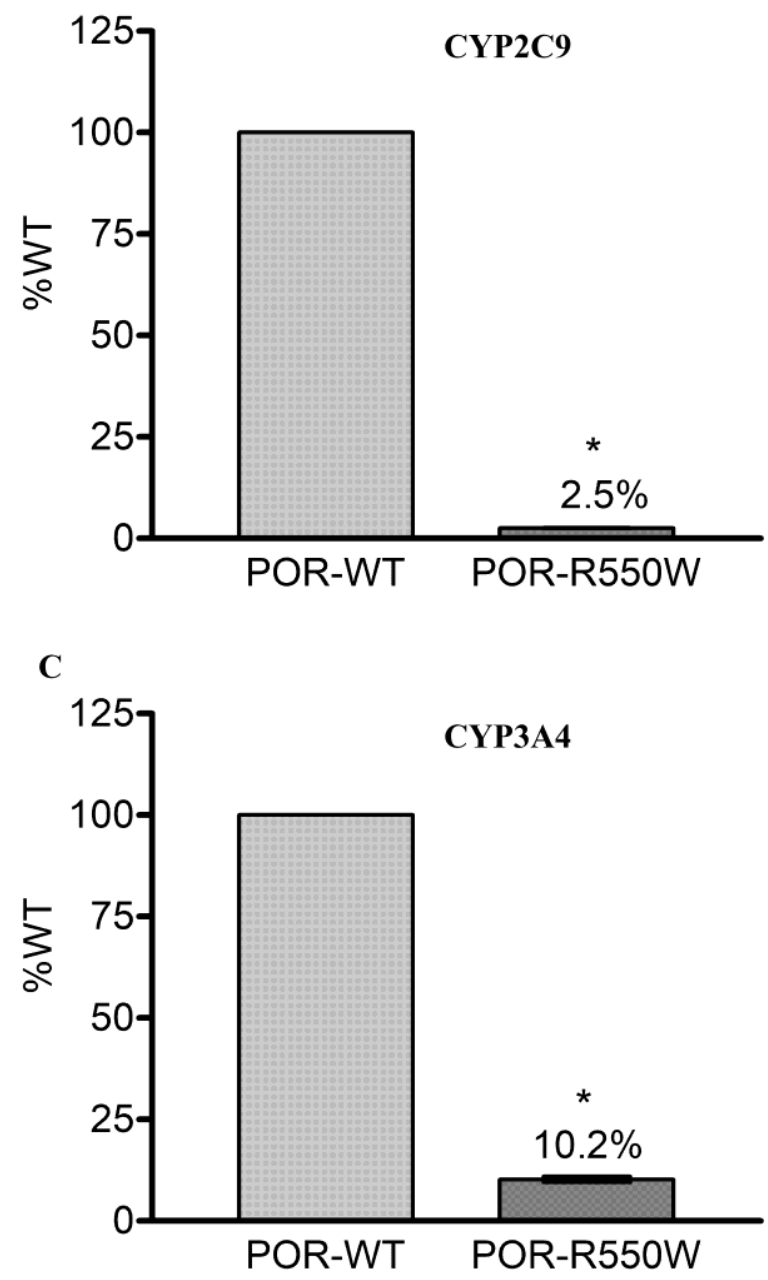

B

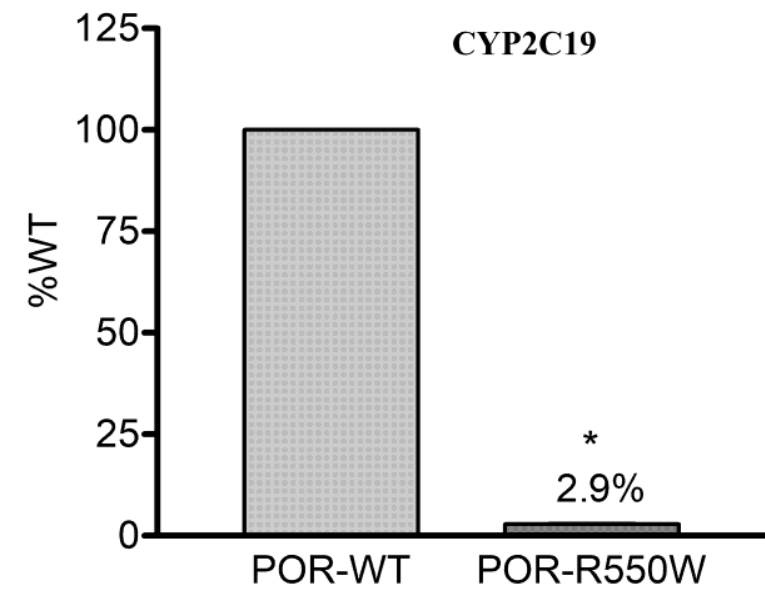

D

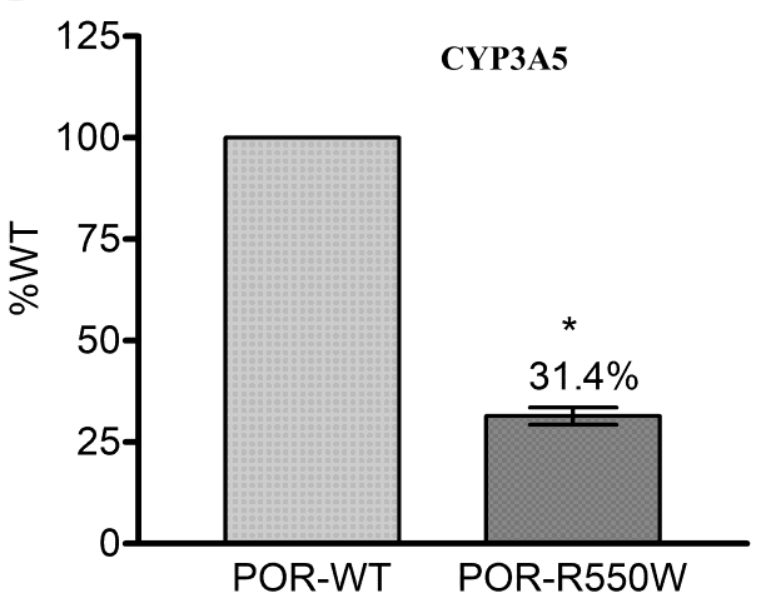


Figure 9

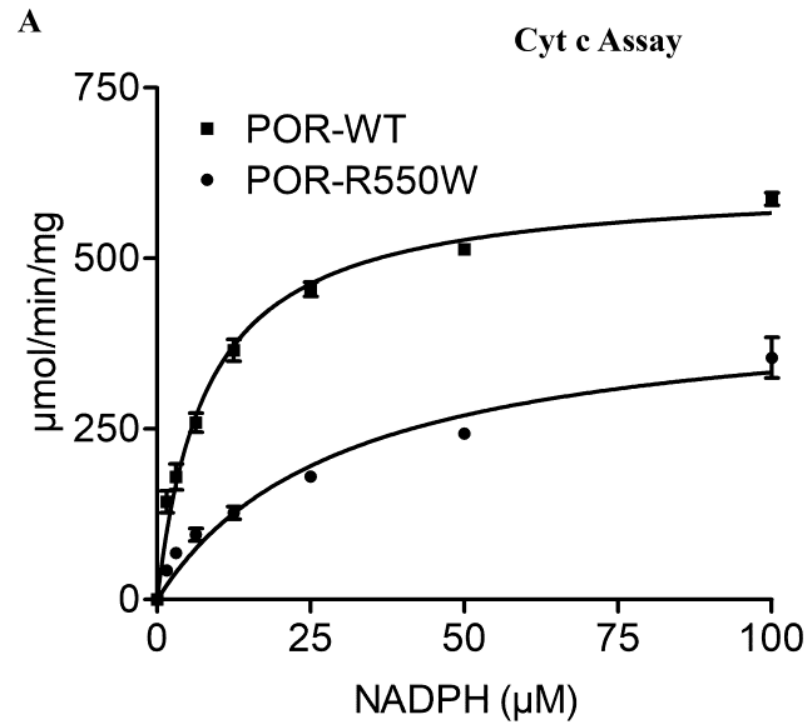

B
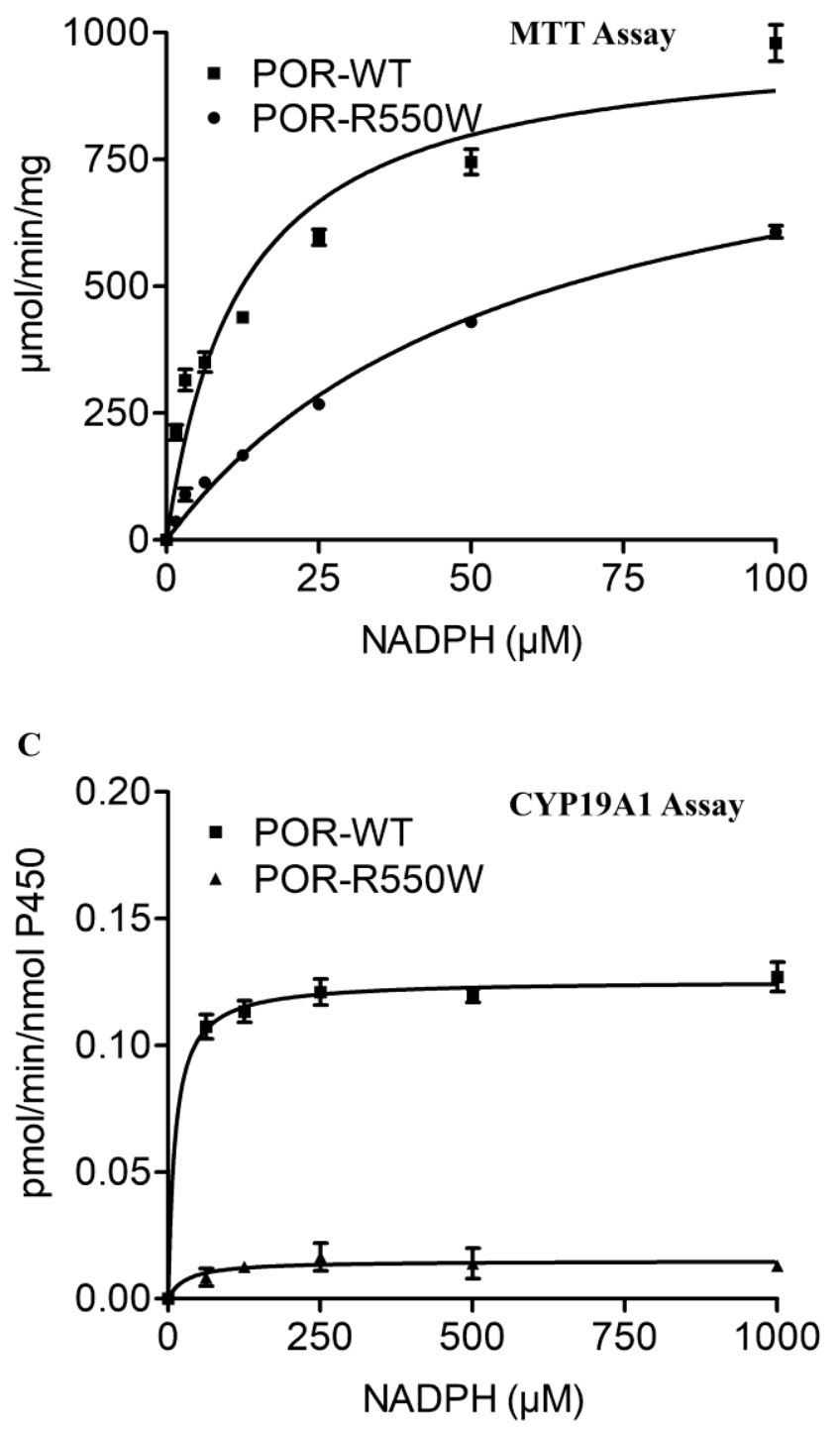
Figure 10
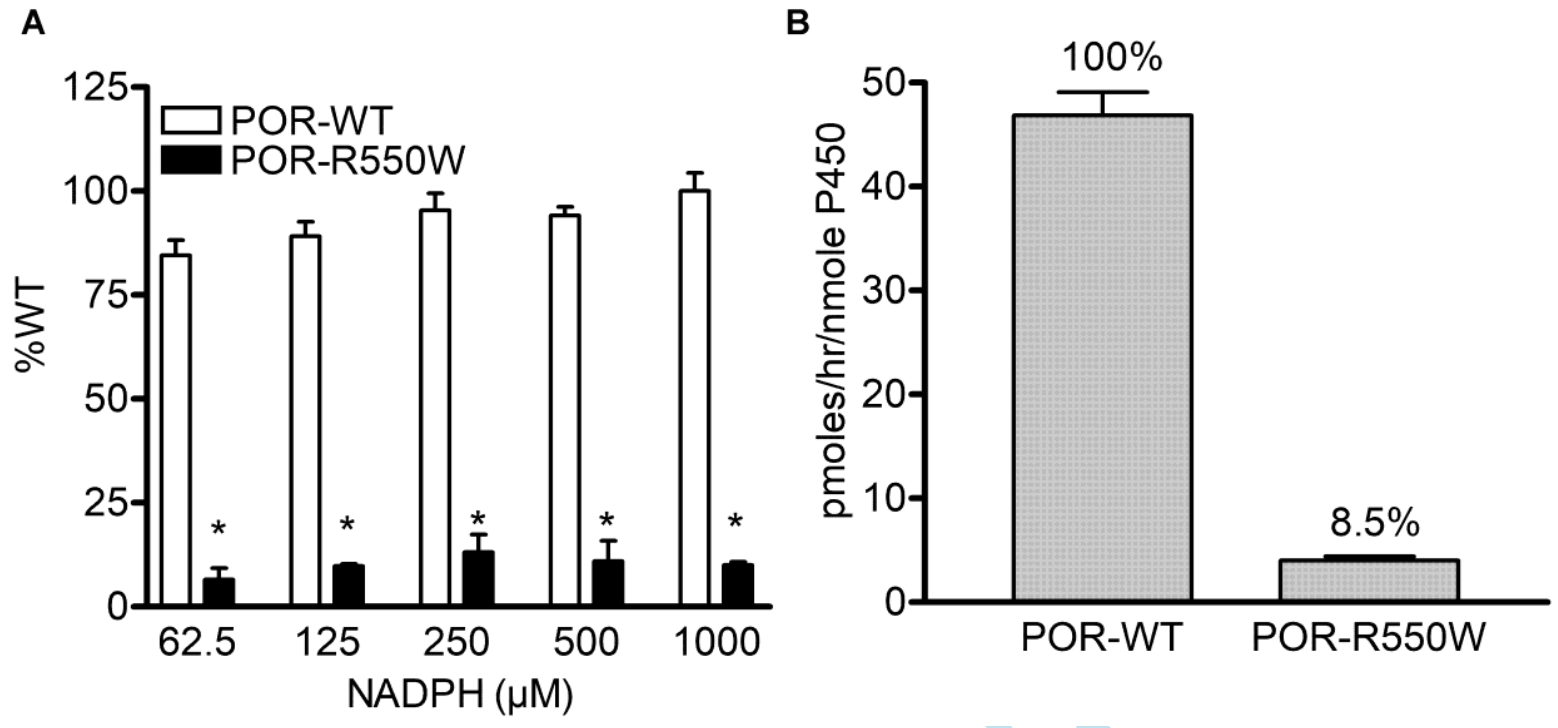